OECDpublishing

\title{
THE 2030 AGENDA AND DEVELOPMENT CO-OPERATION RESULTS
}

OECD DEVELOPMENT POLICY PAPERS

January 2018 No. 9 


\title{
The 2030 Agenda and Development Co-operation Results
}

\author{
Policy Paper 9
}

\author{
By \\ Poul Engberg-Pedersen \\ with contributions by Rosie Zwart
}

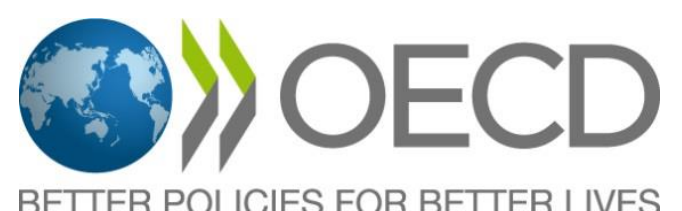




\section{OECD DEVELOPMENT CO-OPERATION POLICY PAPERS}

This paper is published under the responsibility of the Secretary-General of the OECD. The opinions expressed and the arguments employed herein do not necessarily reflect the official views of OECD countries.

The publication of this document has been authorised by Brenda Killen, Deputy Director of the OECD Development Co-operation Directorate.

This document and any map included herein are without prejudice to the status of or sovereignty over any territory, to the delimitation of international frontiers and boundaries and to the name of any territory, city or area.

Comments on the series are welcome and should be sent to dac.contact@oecd.org.

You can copy, download or print OECD content for your own use, and you can include excerpts from OECD publications, databases and multimedia products in your own documents, presentations, blogs, websites and teaching materials, provided that suitable acknowledgement of OECD as source and copyright owner is given. All requests for public or commercial use and translation rights should be submitted to rights@oecd.org.

\section{COPYRIGHT @ OECD 2018}

\section{Keywords:}

Development co-operation results; 2030 Agenda; Sustainable Development Goals; Results targets and indicators; Accountability

\section{JEL codes:}

F35 Foreign Aid; F63 Economic Development; O19 International Linkages to Development $\bullet$ Role of International Organizations; O2 Development Planning and Policy; Q01 Sustainable Development 


\section{ABSTRACT}

Providers of development co-operation can benefit from the Sustainable Development Goals (SDGs), targets and indicators for use in their results frameworks. The paper examines the SDG outcome and performance targets and indicators that fit with the goals of individual providers. It presents a menu of 60 SDG targets and indicators that can strengthen providers' results frameworks, facilitate data collection and use, and offer improved platforms for dialogues on development co-operation results. The concept of "menu" recognises that individual providers and their partners prioritise different aspects of the 2030 Agenda. They can select and apply SDG targets and indicators to their existing results frameworks in accordance with their respective priorities. Results information is used for accountability and communication and hence tied to political goals for development co-operation. With clearer links to the SDGs, results information can also be used for strategic direction and learning by providers. 


\section{Table of Contents}

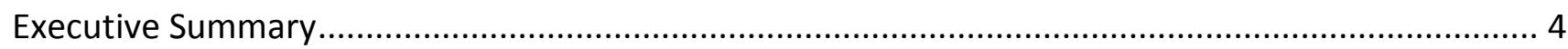

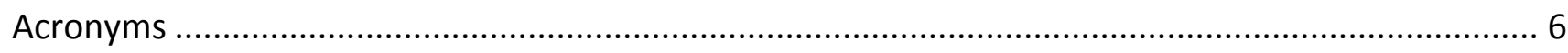

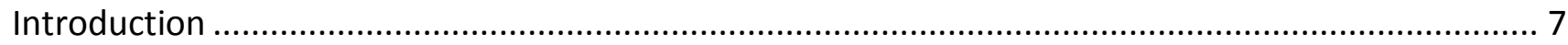

1. Results for accountability, communication, direction and learning ......................................... 10

2. Linking SDG targets and indicators to providers' results frameworks ....................................... 13

3. "Means of implementation" targets \& indicators of provider performance ............................... 15

4. A menu of SDG targets \& indicators for use in provider results frameworks ............................ 17

5. Linking SDG targets \& indicators with providers' standard indicators ....................................... 21

Annex 1: Definitions of results frameworks and approaches....................................................... 23

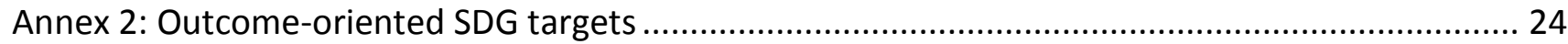

Annex 3: SDG outcome targets supported by robust / tier one SDG indicators ............................. 29

Annex 4: SDG targets and indicators for provider performance: "Means of implementation" in the

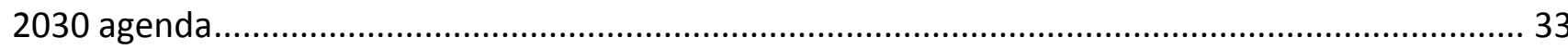

Annex 5: Comparative analysis of selected SDG targets \& indicators and providers' standard

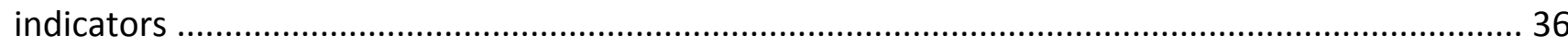

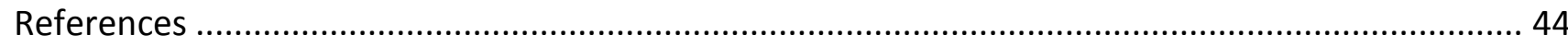

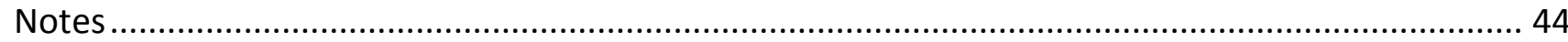

\section{Boxes}

Box 1: Strengthening results frameworks through SDG targets and indicators .................................

Box 2: Examples of SDG means of implementation targets and indicators ......................................17

\section{Tables}

Table 1: The use of information generated in SDG-linked results frameworks .12

Table 2: Breakdown of SDG targets and indicators

Table 3: SDG outcome targets and SDG means of implementation (MOI) targets for possible use in providers' results frameworks

Table 4: Number of standard indicators at Tiers 1 and 2 for development co-operation providers....21

Table 5: Examples of water-related indicators. 


\section{Executive Summary}

Providers of development co-operation can benefit from the Sustainable Development Goals (SDGs), targets and indicators for use in their existing and evolving results frameworks. This paper examines the SDG outcome and performance targets and indicators that can fit with the goals of individual providers. It points to a menu of SDG targets and indicators that can strengthen providers' results frameworks, facilitate data collection and use, and offer improved platforms for dialogues on development co-operation results.

The 2030 Agenda for Sustainable Development expresses the visions and aspirations of the international community, setting up an ambitious results framework with goals, targets, indicators and deadlines (mostly by 2030). The 2030 Agenda offers a results framework for development, but not for development cooperation per se (including official development assistance (ODA)), or for the development co-operation efforts of individual providers.

The 2030 Agenda is not a blueprint for development co-operation; yet, both providers and partners can benefit from linking to the SDGs in their results frameworks. The 2030 Agenda is a political commitment to sustainable development and Leaving no one behind. The Agenda covers practically all official development goals, with the exception of geopolitical and commercial relationships between providers and partners.

The SDG targets aim at real life change for people, societies and the environment. Provider and partner countries are implementing the 2030 Agenda and delivering results from development co-operation. This paper outlines how providers can strengthen their results frameworks and results-based management by incorporating SDG targets and using SDG indicators, for which progress information is being collected. Many providers and partners already identify SDGs and SDG targets that fit with their respective development goals and priorities. This has a number of potential advantages:

a. Providers and partners can identify a commonality of priorities and targets. These can be used for joint programming, results monitoring and results communication, because the SDG targets and indicators are part of a common, internationally agreed framework.

b. Providers and partners can identify gaps in development efforts to meet the partner countries' needs and priorities. Within the government's development priorities, the parties can discuss particular challenges related to the distance to the estimated end values of the 2030 targets.

c. Providers and partners can establish country results frameworks around the SDG targets that are most relevant to their goals for the country's development ${ }^{1}$. These results frameworks may take the form of governments' national plans and budgets and providers' country programmes, built around the SDGs, targets and indicators prioritised by both sides for the country in question.

d. There is already agreement that progress on these SDG targets will be monitored at national level. Hence, SDG progress data will become available for all stakeholders to use, minimising the need for providerspecific results data collection. This is the reason behind the paper's focus on robust SDG indicators.

e. Results frameworks that include SDG targets and indicators generate information, narratives and stories that are well suited for results communication, because they cover real-life change. 
The three-tier results framework ${ }^{2}$ of providers is the starting point (see Annex 1 ). The paper proposes the following menu of SDG targets and indicators for possible use in providers' results frameworks:

1. Tier 1: Development results. Approximately half of the 169 SDG targets are about development outcomes, i.e. real change in basic development parameters. The paper compiles a menu of $\mathbf{4 2}$ SDG targets (covering SDGs 1-16) that are aimed at outcome change and which are supported by robust SDG indicators agreed by the UN Statistical Commission, namely the so-called tier one indicators. ${ }^{3}$ For their results frameworks, providers can include and add goals and targets that are most in line with their own development policy priorities.

2. Tier 2: Development co-operation results. Depending on the precise objectives of individual providers, some of the 42 SDG outcome targets suggested above are better suited to Tier 2 of the results framework. If a provider prioritises, for example, health and inclusive growth in its development cooperation policies and programmes, then it needs outcome targets and indicators for these sectors in Tier 2, whereas SDG outcome targets related to, for example, poverty, inequality and governance would be considered contextual development results (i.e. Tier 1 ) for this provider.

3. Tier 3: Provider performance. Assessing the operational and organisational performance of the provider itself needs data from delivery, financial, and human resource management systems. Most of the targets and indicators used for this are provider-specific, reflecting the policy and management objectives set by the provider. However, the 2030 Agenda includes 62 "means of implementation" (MOI) targets and related indicators. 18 of these SDG-MOI targets and indicators, covering 10 of the 17 goals, offer relevant information on development co-operation performance, outputs and outcomes. They can therefore be used by providers for Tiers 2 and 3 of results frameworks, in accordance with the provider's objectives.

Thus, the paper offers a menu of $\mathbf{4 2}$ SDG outcome targets (supported by 53 robust indicators) for Tiers 1 and 2 of the results frameworks and 18 SDG-MOI targets (supported by 18 robust indicators) for Tiers 2 and 3. Individual providers can select the SDG targets, with supporting robust indicators, which fit with their development co-operation objectives and the reporting requirements for their results frameworks. The authorities of developing countries can incorporate the 42 SDG outcome targets with supporting indicators in their national development results frameworks such as plans and budgets.

This should give providers and partners a common platform and common data for priority setting and results monitoring for country-level development co-operation. ${ }^{4}$

The paper outlines how SDG progress information can support providers' use of results information for accountability, communication, direction (i.e. decision making), and learning. Hitherto, providers have used results information mainly for accountability and communication. The SDG outcome targets and indicators can strengthen this due to the excellent narratives that can be built on the real change captured by the SDGs. In addition, they can strengthen the use of results information for direction and learning, because the SDG progress information reaches across all three Tiers of results frameworks, and because the data are shared by providers, partners and other stakeholders in development co-operation.

For their results and performance monitoring, some providers already apply standard indicators that are supportive of the 2030 Agenda, while focusing on the outputs and reach of their development co-operation. The paper proposes a closer link between such standard indicators and the SDG targets and indicators. 


\section{Acronyms}

CRS

DAC

DCD

DFID

GPEDC

MDG(s)

MOI

ODA

SDC

SDG(s)

WP-STAT
Creditor reporting system, OECD

Development Assistance Committee, OECD

Development Co-operation Directorate, OECD

Department for International Development of the United Kingdom

Global Partnership for Effective Development Co-operation

Millennium Development Goal(s)

Means of implementation

Official development assistance

Swiss Agency for Development and Cooperation

Sustainable Development Goal(s)

DAC Working Party on Development Finance Statistics 


\section{Introduction}

The analysis was prepared for the OECD DAC/DCD Results Community (hereafter, Results Community) workshop on 9-10 October 2017. The workshop found that the SDG targets and indicators are particularly useful in providing common evidence and a platform for dialogue with partners regarding development change, including development co-operation outcomes. SDG progress information can feed into all three Tiers of results frameworks.

The SDG targets are a common framework for the what of development co-operation. The pledge to Leave no one behind concerns the who. The pledge fits well with the goals of development co-operation, but requires strengthened dialogues among providers and partners to agree on who are left behind in particular contexts, and how they can be supported in reaching a faster rate of progress. Box 1 summarises the key messages of the workshop session on "Strengthening results frameworks through SDG targets and indicators".

Purpose: The aim of this policy paper is to enable development co-operation providers to strengthen their results frameworks through incorporation of SDG targets and related indicators. The main benefits are: a focus on real change in the form of outcomes and impacts of development co-operation (i.e. Tiers 1 and 2 of results frameworks, see Annex 1); shared goals and results between providers and partners; strengthened results-based management in partner and provider countries; and cost-effectiveness in the collection of results information. While the focus is on providers' results approaches, the aim is to suggest a menu for SDGlinked results frameworks that have a starting point both in the objectives of development co-operation and in partner countries' national priorities and planning.

The paper offers:

1. An approach for providers of development co-operation to identify SDG targets, indicators and data of relevance to their development policies and to use these in their results frameworks.

2. A menu of 42 SDG outcome targets, supported by 53 robust SDG indicators, that providers and partners can consider as components of results frameworks for development co-operation.

3. A menu of 18 SDG targets and indicators covering "means of implementation" that can be included in Tiers 2 or 3 of results frameworks concerning provider performance and outcomes.

4. An assessment of the standard indicators applied by many providers and the scope for linking these directly to SDG targets and indicators, for all three Tiers of providers' results frameworks.

A parallel note addresses "Development co-operation results for the 2030 Agenda: A guide for applying the Sustainable Development Goals, targets and indicators in results frameworks" (OECD, 2018).

Figure 1 pulls together the storyline and the suggested menu of SDG targets and indicators for possible inclusion in the results frameworks of providers and partners.

Figure 1 can be read in two ways. From the left: The 2030 Agenda includes several results-oriented SDG targets and indicators of relevance to the existing or emerging results frameworks of providers and partners. From the right: Providers and partners have goals, priorities and results frameworks for development and development co-operation that can be strengthened with relevant SDG targets and indicators.

Box 1 below shows the key messages emerging from the Results Community workshop (October 2017) with respect to the workshop session: Strengthening results frameworks through SDG targets and indicators. 


\section{Linking Provider Results Frameworks to the SDGs}






\section{Box 1: Strengthening results frameworks through SDG targets and indicators}

The 2030 Agenda is a useful framework for providers and partners in development co-operation. With its 17 goals, 169 targets, 232 indicators and given deadlines (mostly 2030), the 2030 Agenda serves as a global and country-level results framework for sustainable development results, to which development co-operation contributes.

Development policies increasingly refer to all or some of the SDG goals and targets and the pledge to Leave no one behind. Some providers already incorporate SDG targets and indicators in their results frameworks, sometimes through standard indicators for use at country or corporate levels. Some partner country representatives described how the achievement of SDG goals and targets is incorporated into their national plans and budgets and even in their public sector performance agreements. Yet, caution was also raised against excessive reliance on SDG indicators - and quantitative indicators in general - which may bias results assessment efforts towards activities that can be measured.

The advantages of linking results frameworks to SDG targets and indicators include:

- The 2030 Agenda offers an internationally agreed framework for sustainable development results. Going beyond the broad goals to include SDG targets in results frameworks enhances the scope for coherent and operational goals-results links, since most of the SDG targets are concrete, substantive and monitorable. Some suggested 'adding' to the three tiers of results frameworks, because SDG-linked data feed into the areas between development and development co-operation results and between the latter and provider performance, i.e. 'Tiers 1.5 and 2.5 ' in the results frameworks.

- With a focus on SDG targets that aim at outcome change by the target date of 2030, providers and partners can acquire development results information for accountability, communication, direction and learning. The Results Team has developed an approach to identify SDG targets that aim at outcome change and are relevant to particular development co-operation objectives and portfolios. The approach offers a common, evidence-based platform for results dialogue between providers and partners. It can lift the dialogue to matters of development impact and change - the ultimate purpose of results information and development co-operation.

- Information on the means of implementation targets of the 2030 Agenda can feed into the output and performance assessment elements of providers' results frameworks, since they give information on the efforts made by providers under relevant SDGs. Gradually, data will become available for countries and globally on progress towards the SDG targets as development results. There should be less need for providerspecific data collection for results frameworks.

- The data and information collected by partner countries and international organisations can contribute to all three tiers of results frameworks: development results; development co-operation results; and performance monitoring. The Results Team identified a menu of 42 outcome-focused SDG targets, supported by 53 robust SDG indicators, and 18 means of implementation targets, supported by 18 robust indicators. The menu is indeed a menu, suggesting a set of SDG targets and indicators that are relevant to providers and partners, who should select and focus on the targets and indicators that are most useful to their development cooperation policies and portfolios.

Many providers are actively seeking ways to link their results frameworks to SDG targets and indicators, for which the proposed menu will be useful. Linking SDG targets and indicators to results frameworks should be a complementary process to mapping SDGs to development co-operation inputs and portfolios, which many providers are undertaking at either the goal or target levels. It was suggested that the Results Team examine the possibility of a decision-tree for providers and partners to assess and strengthen their existing results frameworks. Country-level dialogues based on SDG progress information could strengthen mutual accountability for development results, while acknowledging that both providers and partners need additional, context-specific information in their results frameworks.

Source: OECD (2017a), "Key Messages from Results Community Workshop, 9-10 October 2017", http://www.oecd.org/dac/results-development/docs/Results-oct-2017-Key-Messages.pdf 


\section{Results for accountability, communication, direction and learning}

Earlier papers and workshops for the Results Community ${ }^{5}$ have identified four typical purposes of the generation and use of results information by providers and their partners in developing countries: enhancing accountability, strengthening communication, supporting decisions on direction, and enabling evidence based learning. Many providers emphasise accountability and communication, and face challenges in using results information systematically for direction and learning. Furthermore, results information is often used separately for corporate, domestic purposes and for country-level accountability and programming purposes. Can an SDG-linked results framework address these challenges by generating results information for all four purposes and by better linking corporate and country-level results frameworks?

\subsection{Accountability}

An advantage of SDG-linked results frameworks is that both providers and partners will get access to progress information on the SDG targets prioritised by either provider or partner. Developing countries are committed to collect and provide progress information on SDG targets. Such progress is equivalent to development results and therefore of direct use for providers and partners at Tier 1 of their results frameworks. This information should gradually cover all SDGs and targets, but developing countries may rightfully emphasise progress monitoring for those SDGs and targets that they each prioritise politically. If a partner or provider country prioritises, for example, poverty reduction, health, growth and equality in their policy goals for development and development co-operation, then Tier 1 of results frameworks can be filled with development results in the form of SDG progress information.

The development co-operation results at Tier 2 are also concerned with outcomes. The SDG targets and indicators are sufficiently detailed to enable providers of development co-operation to identify and select SDG targets, for which they can get progress information (both globally and at country level) that enable conclusions on whether real change on the ground is heading in the right direction, and hence whether their development co-operation is relevant. If providers seek such SDG target progress information for the countries where the provider has significant portfolios aimed at particular targets, then the provider can also conclude that its programmes contribute to results in the form of SDG progress. This is real accountability.

Incorporating SDG targets and indicators in the results frameworks of providers and partners is the most effective approach towards mutual accountability. It can give substance to mutual accountability, which often has been more about inputs and allocations and the platforms and procedures of dialogue (between providers and partners) than about the substance of the dialogue and the actual development results achieved through joint efforts of development co-operation. Progress information on SDG targets that are prioritised by both providers and partners tells about actual development results.

Similarly, the peer reviews of providers that are a major element of DAC's work can have stronger, substantive reference frameworks for their assessments when all providers and partners incorporate SDG targets and indicators in their results frameworks. The DAC can have substantive, SDG-specific dialogues on the contribution of development co-operation, including the portfolios of individual providers, to the development results achieved in the form of SDG progress. The same applies to debates in UN bodies dealing with the effectiveness of development co-operation and its contribution to the implementation of the 2030 Agenda for Sustainable Development. 


\subsection{Communication}

Incorporating SDG targets and indicators in providers' results framework promises to strengthen results communication in multiple ways: It gives substance to the narratives and potentially the stories that results communication needs for all constituents. For many bilateral providers, communicating positive results about development co-operation to the domestic political level and to tax payers is a primary driver behind the generation and use of results information, i.e. behind the establishment of results frameworks.

The more providers can justifiably point to relevant development outcomes in the form of selected, prioritised SDG targets, the easier it is to generate support for development co-operation. The narratives are self-evident when a link is made to the universal 2030 Agenda for Sustainable Development - while other narratives (e.g. on geopolitical objectives and stakeholder engagement) are also needed by individual providers. The human features of real-life situations that are reflected in the SDG targets and indicators are directly useful entry points for evidence- and story-based results communication.

Furthermore, the dialogue between providers and partners can start from a communication of results that are essential to both parties. Dialogue on development co-operation often deals primarily with the project cycle, policy and programme formulation and agreement on respective roles during implementation. Greater emphasis on outcome change will improve the dialogue. SDG-linked results frameworks can encourage wider participation in the dialogues, including by the intended beneficiaries, because the results information deals with concrete outcome change. It can be examined whether the intended results of development cooperation are also the priorities of the intended target groups and other stakeholders. The attempts to listen to the "voices of the poor" can be made more substantive and politically relevant through the inclusion of SDG targets and indicators used by both providers and partners.

\subsection{Direction}

Providers use results information only sporadically for assessing and setting the direction and strategic priorities of development co-operation. The argument may be that results information, such as the World Bank's scorecards, covers only a fraction of the operations supported by the provider. ${ }^{6}$ If, however, results information is linked to progress and challenges on the SDGs, it will enable reassessments of priorities for development co-operation, if only in a contributory and leveraging role. By integrating information on progress of SDG targets prioritised by individual providers, they can link it to other evidence on the challenges for the SDG targets in question - evidence which is being provided by national statistical offices in developing countries and by multilateral organisations inside and outside the UN.

Improved transparency is another benefit of the use of SDG-linked results information for better decisions on the direction of development co-operation, because of the joint evidence available for decision making either with partners at country level or in provider co-ordinated initiatives and programmes. The scope for joint monitoring and evaluation efforts is significantly expanded, if they can be based on common SDG targets and indicators. Finally, better evidence on the contribution of development co-operation to the SDGs will enable collective decision making in UN and other international bodies on challenges, gaps and investment priorities, because decisions can be based on common evidence (of SDG progress), and because the links between development co-operation objectives and SDG targets become clearer for more providers. 


\subsection{Learning}

SDG-linked results frameworks promise to reduce the risk of providers having two unrelated types of results frameworks: a corporate results framework used mainly for internal and domestic purposes, and providerspecific country results frameworks used for portfolio management in partner countries. When providers use standard indicators, including selected SDG indicators, which cover country operations and global programming, the chances are improved for use of results information for learning. The links between results frameworks and programming will be shorter because of the SDG evidence relevant to all levels and uses.

Furthermore, reliance on SDG indicators in results frameworks by both partner countries and providers will enhance the scope for capacity development through joint learning on results-based management. SDGlinked results frameworks can enable international bodies to engage in collective learning on the links between the what (progress on the 2030 Agenda and the SDGs), the who (Leave no one behind) and the how (development co-operation and other channels of financing for development).

Table 1 summarises the strengths of SDG-linked results frameworks for all four uses of results information. It should be noted that SDG-linked results frameworks cannot replace current results frameworks that may include a focus on delivery and performance of providers (Tier 3 of results frameworks). Individual providers should pursue their use of results frameworks to monitor their adherence to the development effectiveness principles. The so-called "means of implementation" targets and related indicators of the SDGs can only contribute in part, as discussed below.

Table 1: The use of information generated in SDG-linked results frameworks

\begin{tabular}{|c|c|c|c|}
\hline $\begin{array}{l}\text { Use of SDG-linked } \\
\text { results information }\end{array}$ & $\begin{array}{l}\text { Individual providers of } \\
\text { development co-operation, } \\
\text { bilateral and multilateral }\end{array}$ & $\begin{array}{l}\text { Country-level partnerships } \\
\text { of providers and partner } \\
\text { authorities }\end{array}$ & $\begin{array}{l}\text { International governance of } \\
\text { development co-operation: DAC, } \\
\text { GPEDC, UN-HLPF, UN-DCF }{ }^{7}\end{array}$ \\
\hline 1) Accountability & $\begin{array}{c}\text { Evidence on partner country } \\
\text { progress on SDG targets } \\
\text { prioritised by the provider }\end{array}$ & $\begin{array}{l}\text { Foundation for provider and } \\
\text { partner to assess and report } \\
\text { on progress, country-led }\end{array}$ & $\begin{array}{l}\text { Substance for peer reviews and } \\
\text { effectiveness assessments of } \\
\text { development co-operation }\end{array}$ \\
\hline 2) Communication & $\begin{array}{l}\text { Progress on the provider's } \\
\text { contributions and policy } \\
\text { coherence on } 2030 \text { Agenda }\end{array}$ & $\begin{array}{l}\text { Creating space for voices of } \\
\text { beneficiaries on their } \\
\text { priorities and progress }\end{array}$ & $\begin{array}{l}\text { Raising debates above systems } \\
\text { level and showing leadership on } \\
\text { SDG implementation }\end{array}$ \\
\hline 3) Direction & $\begin{array}{l}\text { Progress on identified SDG } \\
\text { targets enabling providers } \\
\text { to reassess own priorities }\end{array}$ & $\begin{array}{l}\text { SDG-linked planning and } \\
\text { results frameworks enable } \\
\text { transparent priority-setting }\end{array}$ & $\begin{array}{l}\text { Mobilising resources for the } 2030 \\
\text { Agenda reflecting dev coop } \\
\text { contributions }\end{array}$ \\
\hline 4) Learning & $\begin{array}{l}\text { Links corporate } \& \text { country } \\
\text { level results frameworks, for } \\
\text { use in corporate learning }\end{array}$ & $\begin{array}{l}\text { Relevance of development } \\
\text { co-operation and supporting } \\
\text { results-based management }\end{array}$ & $\begin{array}{l}\text { Monitoring changes in the } 2030 \\
\text { WHAT and WHO as the } \\
\text { framework for reforms of HOW }\end{array}$ \\
\hline
\end{tabular}




\section{Linking SDG targets and indicators to providers' results frameworks}

Providers must take an analytical approach to the 169 SDG targets and 232 SDG indicators, in order to achieve the benefits from strengthening their results frameworks with selected SDG targets and indicators. Table 2 summarises the UN's breakdown of the SDG targets and indicators as of mid-2017. ${ }^{8}$ It shows the distinction between targets and "means of implementation" (MOI) targets. ${ }^{9}$

Table 2 points to some challenges for results frameworks that use SDG targets and indicators. All goals have both targets and $\mathrm{MOI}$ targets attached to them, yet there is no clear and common definition of a target. The number of total targets per goal varies from 5 to 19, though with no explanation for this diversity. There is a perception that the goals and targets of the Millennium Development Goals (MDGs) (covering the years 20002015) still dominate international efforts. ${ }^{10}$ However, Table 2 does not suggest that the poverty, health and education targets known also from the Millennium Declaration are more elaborate or easier to work towards (or even reach), than the goals on equality, environment and human rights added under the 2030 Agenda. The robust SDG indicators are well spread across the 17 SDGs, though still dominated by health indicators.

Table 2: Breakdown of SDG targets and indicators

\begin{tabular}{|lcc|}
\hline Sustainable Development Goals & $\begin{array}{c}\text { General targets / } \\
\text { MOI targets }\end{array}$ & $\begin{array}{c}\text { No of robust indicators for general / } \\
\text { MOI targets, respectively }\end{array}$ \\
\hline 1) No poverty & $5 / 2$ & $2 / 0$ \\
\hline 2) Zero hunger & $5 / 3$ & $4 / 2$ \\
\hline 3) Good health and well-being & $9 / 4$ & $10 / 3$ \\
\hline 4) Quality education & $7 / 3$ & $2 / 2$ \\
\hline 5) Gender equality & $6 / 3$ & $2 / 1$ \\
\hline 6) Clean water and sanitation & $6 / 2$ & $2 / 2$ \\
\hline 7) Affordable and clean energy & $3 / 2$ & $4 / 0$ \\
\hline 8) Decent work and economic growth & $10 / 2$ & $8 / 1$ \\
\hline 9) Industry, innovation and infrastructure & $5 / 3$ & $6 / 2$ \\
\hline 10) Reduced inequalities & $7 / 3$ & $3 / 2$ \\
\hline 11) Sustainable cities and communities & $7 / 3$ & $2 / 0$ \\
\hline 12) Responsible consumption \& production & $8 / 3$ & $1 / 0$ \\
\hline 13) Climate action & $3 / 2$ & $0 / 0$ \\
\hline 14) Life below water & $7 / 3$ & $2 / 0$ \\
\hline 15) Life on land & $9 / 3$ & $2 / 2$ \\
\hline 16) Peace, justice and strong institutions & $10 / 2$ & $5 / 1$ \\
\hline 17) Partnerships for the goals & $0 / 19$ & $0 / 15$ \\
\hline No. of SDG targets and robust indicators & $\mathbf{1 0 7} / \mathbf{6 2}$ & $\mathbf{5 5} / \mathbf{3 3}$ \\
\hline
\end{tabular}

Below and in Annexes 3 and 4, only robust SDG indicators are considered. The Inter-Agency Expert Group on SDG Indicators is likely gradually to characterise more SDG indicators as robust, meaning that they are moved into the tier one category. Therefore, the analysis in this paper offers only a menu of SDG-linked targets and indicators that can be updated as the list of robust indicators is expanded. With respect to climate action, no tier one SDG indicators are available because this was left to the Paris Agreement on Climate Change. ${ }^{11}$ The menu should be updated accordingly. 


\section{Outcome targets and robust SDG indicators}

The 2030 Agenda includes 169 targets, and the UN Statistical Commission has confirmed 232 SDG indicators. ${ }^{12}$ In earlier analyses for the Results Community, an attempt was made to identify those SDG targets that aim at documentable change (by 2030) in the form of concrete outcomes for people, societies or the environment. Annex 2 lists 89 outcome-oriented SDG targets, out of the $169 .{ }^{13}$ It does not list the 62 means of implementation targets, nor 18 targets considered to aim more at processes than outcomes.

It should be noted that the distinction between outcome targets and MOI targets in the 2030 Agenda is not clear, and development co-operation is aimed also at strengthened institutions, partnerships and policies, which are often more than means of implementation. The distinction is maintained here, to enhance the focus on substantive change in results frameworks. Section 3 below examines what MOI targets and indicators may be useful for Tier 3 (and to some extent Tier 2 ) of results frameworks, dealing with provider performance.

The next step in the consideration of an SDG-linked results framework is to focus on SDG outcome targets that are supported by robust / tier one SDG indicators. ${ }^{14}$ For the 89 SDG outcome targets examined here, 42 targets are supported by 53 robust indicators, as shown in Annex 3. They constitute the SDG-linked outcome targets and robust SDG indicators proposed as a menu for development co-operation results frameworks, together with some means of implementation indicators used to assess provider performance (see Section 3 and Annex 4). The further development and use of this menu must consider that the coverage of SDG outcome targets and robust SDG indicators falls in three groups:

- Some SDGs are well covered by outcome targets and robust indicators: SDGs 1) on poverty; 2) on hunger; 3) on health; 6) on water and sanitation; 7) on energy; and 8) on growth.

- Some SDGs are only partly covered by outcome targets and robust indicators: SDGs 4) on education; 9) on infrastructure, industrialisation and innovation; 11) on urbanisation; 14) on life under water; and 16) on peace, justice and accountable institutions.

- Some SDGs are not well covered by outcome targets and robust indicators: SDGs 5) on gender equality; 10) on inequality; 11) on sustainable consumption and production; 13) on climate change; and 15) on life on land. ${ }^{15}$

This reintroduces the challenge of moving from the MDGs to the SDGs. While the SDGs thematically are more comprehensive than the MDGs, the list cannot cover all geopolitical and thematic goals pursued by providers through development co-operation. The development dimensions that are hardest to cover with clear SDG outcome targets and robust indicators concern gender, social, economic and political equality and environmental sustainability.

To summarise: Annex 3 lists $\mathbf{4 2}$ SDG targets that are supported by 53 robust SDG indicators. These 42 SDG targets address countries' progress towards the 2030 targets that relate to outcome and impact change, i.e. the ultimate levels of the results chain. However, as has been the case through decades of development cooperation, finding data to capture results related to politics and social change remains the greatest challenge.

Progress on the SDG targets listed in Annex 3 can provide evidence on change towards 2030 and indirectly on development co-operation's contribution to development results, but must be supplemented by performance 
data and results narratives to provide all the information needed for providers' results frameworks. Achieving progress on these SDG targets is equivalent to achieving development results, with development co-operation in a contributory role. It should be emphasised that Annex 3 lists only those SDGs that: a) aim at outcome change (see Annex 2); and b) are supported by robust SDG indicators, classified as tier one by the UN Statistical Commission.

Providers can compare this list to the goals and targets in their existing development co-operation results framework and to the standard results indicators that they may apply for Tiers 1 and 2 of results frameworks, covering development results and development co-operation results, respectively. The more they can achieve the purpose of their development co-operation results framework by incorporating the SDG targets and indicators, the better it is for providers in terms of regular data availability and a shared foundation with partners for dialogues on gaps, priorities and progress.

The focus here is on providers and their results frameworks for development co-operation. However, the targets and indicators in Annex 3 are universal, and the aim of introducing them in providers' results frameworks is also that they can build on and strengthen the results frameworks of partner countries that often take the form of national development plans and budgets. ${ }^{16}$ The 2030 Agenda for Sustainable Development is explicit in its emphasis that the SDGs must be owned, prioritised and adapted by each country. The 17 goals and 169 targets are not a straight-jacket. The draft of this paper (discussed at the October 2017 workshop of the Results Community) included evidence from some partner countries on their approaches to capturing the 2030 Agenda in results-oriented development planning and management, including in development co-operation results.

Based on efforts to incorporate SDGs, targets and indicators in planning and programming, providers and partners of development co-operation can:

- Identify and use commonality of SDG targets between the partner government's national plans, budgets and results frameworks on one hand and the country programmes of the provider on the other. This supports national ownership without preventing providers from pursuing their own goals, recognising that the 2030 Agenda is a common ambition. Partner country authorities may have desires for particular roles for different providers (e.g. multilateral banks for private sector or infrastructure development), which again can be captured in the common SDG framework.

- Contribute to effective results-based management by partner authorities by minimising provider-specific results frameworks and information collection and maximising the use of administrative data and national SDG monitoring. The providers have committed to this through the Paris-Busan principles of development effectiveness. By searching for overlapping results frameworks with SDG targets and indicators, this approach can at the same time strengthen planning and results management by partner authorities and providers' country-specific portfolio management and results reporting.

\section{3. "Means of implementation" targets \& indicators of provider performance}

Tier 3 of provider results frameworks typically demonstrates operational and organisational performance. At Tier 3, input data from financial, aid and human resource management systems show how well an aid agency is performing - for example the number of projects funded, the quality of delivery, the amount of ODA spent in a given sector or category, the percentage of ODA delivered as planned, the use made of developing 
country systems or the turnover of staff. Performance information includes inputs and management information and is not classified as "results". However, performance data are important for decision making. They can inform and enable insights from results information, and therefore form part of the results chain (OECD, 2017b). This section examines the scope for applying the MOI targets and indicators of the 2030 Agenda to providers' results frameworks. The means of implementation targets and indicators are about the necessary policies, partnerships and resources required to achieve the SDGs. With this in mind, relevant MOI targets and indicators could potentially be used to strengthen provider results frameworks and reinforce links to the SDGs.

Annex 4 presents a menu of SDG MOI targets and indicators of which a relevant subset could be selected for use in provider results frameworks. The menu was reached by analysing how relevant $\mathrm{MOI}$ targets and indicators of the 2030 Agenda are to development co-operation, and whether and how the targets and indicators could be incorporated into the results frameworks of providers. As demonstrated in Annex 4, 18 of the $62 \mathrm{MOI}$ targets in the SDG framework were assessed as being directly relevant to development cooperation as well as having corresponding robust indicators. These 18 targets and their indicators cover 10 of the 17 SDG Goals ${ }^{17}$.

While the language of the 18 identified $\mathrm{MOI}$ targets tends to cover both inputs and results, the corresponding indicators can be categorised into two broad categories: a) Indicators which measure and monitor development co-operation finance (inputs) - 11 indicators; and b) Indicators which measure development outputs and outcomes (to which development co-operation directly contributes) -7 indicators. Box 2 offers examples of these two categories of SDG-MOI targets and indicators.

The targets and indicators in category a) above could be used in Tier 3 of results frameworks to document the resources contributed by specific providers in support of achieving particular SDG goals and targets. It is important to note that data about a provider's contribution to these targets would only form part of a provider's overall performance story, and would only be relevant if these sectors were considered a policy priority by that provider. The data for all the indicators in the first category are readily available - by provider - via CRS reporting. The small group of $\mathrm{MOI}$ targets and indicators in category b) above might more usefully be incorporated into Tier 2 of provider results frameworks to demonstrate contribution toward outputs and outcomes.

By using the SDG targets and their indicators (exemplified in Box 2), providers could meaningfully link to SDG 6 and/or 9, and tangibly demonstrate contribution towards these targets, again only where the targets are relevant to that provider's sectoral focus, and where the provider delivers projects which would generate results toward these targets. For example, for indicator 9.c.1 where a provider is funding infrastructure to enable mobile phone coverage, the provider might use this indicator to show its contribution towards an increased access to mobile coverage both in terms of number of people and the proportion of the population.

As such, Annex 4 presents a menu of $\mathrm{MOI}$ targets and indicators which could be incorporated into provider results frameworks at either Tier 2 or Tier 3 . The advantage of incorporating $\mathrm{MOI}$ targets and/or indicators (together with other relevant performance and results information) into provider results frameworks is that it helps to:

- Meaningfully demonstrate the contribution of development co-operation towards SDG progress 
- Link provider results frameworks to the SDGs; thus operationalising the SDGs

- Strengthen the results chain by explicitly linking the inputs of development co-operation with SDGs that are prioritised by both provider and partner

- Strengthen harmonisation of indicators among providers and with partners.

Box 2: Examples of SDG means of implementation targets and indicators

MEASURING DEVELOPMENT CO-OPERATION FINANCE (INPUTS):

Target:

2.a Increase investment, including through enhanced international cooperation, in rural infrastructure, agricultural research and extension services, technology development and plant and livestock gene banks in order to enhance agricultural productive capacity in developing countries, in particular least

\section{Indicator:}

2.a.2 Total official flows (official development assistance plus other official flows) to the agriculture sector developed countries

Target:

6.a By 2030, expand international cooperation and capacitybuilding support to developing countries in water-and sanitation-related activities and programmes, including water harvesting, desalination, water efficiency, wastewater treatment, recycling and reuse technologies

Indicator:

6.a.1 Amount of water and sanitationrelated official development assistance that is part of a government coordinated spending plan

\section{MEASURING DEVELOPMENT OUTPUTS AND OUTCOMES:}

Target:

6.b Support and strengthen the participation of local communities in improving water and sanitation management

Target:

9.c Significantly increase access to information and communications technology and strive to provide universal and affordable access to the Internet in least developed countries by 2020
Indicator:

6.b.1 Proportion of local administrative units with established and operational policies and procedures for participation of local communities in water and sanitation management

Indicator:

9.c.1 Proportion of population covered by a mobile network, by technology

\section{A menu of SDG targets \& indicators for use in provider results frameworks}

The menu of SDG-linked results targets and indicators, which is outlined in this paper, is a framework for monitoring development results, of potential use to both providers and partner country authorities. The information gathered can provide evidence on the relevance and contribution of development co-operation to development results, but it cannot deliver evidence on the attribution of results to development cooperation, let alone to the portfolio of an individual provider.

Two criteria are behind this menu of SDG targets and indicators that can be used to strengthen the results frameworks of development co-operation providers - and of their partners among developing countries. First, 
the SDG targets shall be relevant to the three Tiers of results frameworks. Second, the SDG indicators shall be robust and with good data availability; this is achieved by focusing on the tier one category of SDG indicators approved by the UN Statistical Commission. Table 3 shows the proposed menu of SDG targets and indicators, by individual SDGs. The following features are essential:

- With a total of 60 SDG targets supported by 71 SDG indicators, it is indeed a menu for the three Tiers of results frameworks. Providers can choose the targets (and related indicators) that are most relevant to their individual development co-operation goals and objectives and the information and reporting required from their results frameworks.

- Each provider and partner would have to assign SDG outcome targets and indicators to either Tier 1 or Tier 2 of their results frameworks, since outcome results are found at both Tiers. What may be a contextual development result for one provider (e.g. health or growth), may be the pursued development co-operation outcome of another provider. This adaptation to individual providers' results frameworks is not a problem, since the key is that information is actually being collected, made accessible to and used by all stakeholders.

Table 3: SDG outcome targets and SDG MOI targets for possible use in providers' results frameworks

\begin{tabular}{|c|c|c|}
\hline $\begin{array}{l}\text { Sustainable Development } \\
\text { Goals }\end{array}$ & $\begin{array}{l}\text { SDG outcome targets for Tiers } 1 \\
\text { and } 2 \text { of results frameworks: } \\
\text { Development results and } \\
\text { development co-operation results }\end{array}$ & $\begin{array}{l}\text { SDG MOI targets for Tiers } 2 \text { and } 3 \\
\text { of results frameworks: } \\
\text { Development co-operation results } \\
\text { and provider performance }\end{array}$ \\
\hline 1) No poverty & 2 targets & 0 targets \\
\hline 2) Zero hunger & 2 targets & 1 target \\
\hline 3) Good health \& well-being & 7 targets & 2 targets \\
\hline 4) Quality education & 2 targets & 3 targets \\
\hline 5) Gender equality & 1 target & 0 targets \\
\hline 6) Clean water \& sanitation & 2 targets & 2 targets \\
\hline 7) Affordable \& clean energy & 3 targets & 0 targets \\
\hline 8) Decent work and growth & 6 targets & 1 target \\
\hline 9) Industry, innovation, infra & 3 targets & 2 targets \\
\hline 10) Reduced inequalities & 2 targets & 1 target \\
\hline 11) Sustainable cities, comm. & 2 targets & 0 targets \\
\hline 12) Responsible con. \& prod. & 1 target & 0 targets \\
\hline 13) Climate action & 0 targets & 0 targets \\
\hline 14) Life below water & 2 targets & 0 targets \\
\hline 15) Life on land & 1 target & 1 target \\
\hline 16) Peace, justice, institution & 6 targets & 1 target \\
\hline 17) Partnerships for goals & 0 targets & 4 targets \\
\hline Proposed menu & 42 targets w. 53 robust indicators & 18 targets $w .18$ robust indicators \\
\hline
\end{tabular}

- Similarly, each provider would have to assign SDG MOI targets and indicators to either Tier $\mathbf{2}$ or Tier $\mathbf{3}$ of their results frameworks. The reason is that these $\mathrm{MOI}$ targets are a mixture of input, output and outcome targets and indicators. While the key strength is that they will provide directly useful 
information for the results frameworks, it should be emphasised that these $\mathrm{MOI}$ indicators address only a limited part of a provider's performance.

- The emphasis of the proposed menu is on SDG targets. The results chain highlights that a results framework should always link outputs, outcomes and impact to the goals and objectives pursued. While change happens and can stand on its own, results (whether positive or negative) can only be assessed relatively to goals. The SDG targets are an unusual opportunity for internationally agreed objectives against which development co-operation achievements can be assessed. Linking results frameworks to the SDGs is a way to operationalise and substantiate providers' accountability towards delivering the 2030 Agenda for Sustainable Development.

- The strength of the proposed menu lies in the direct support, which the robust tier one SDG indicators can give to information collection for the SDG targets. The tier one indicators are defined by the availability of data for many countries, which means that providers can choose relevant SDG targets with indicators and data for consideration in their results frameworks.

These features give providers the flexibility needed to incorporate SDG targets and indicators in their existing results frameworks. They confirm that what is proposed here is not a blueprint SDG-linked results framework, let alone a straitjacket, but a menu of SDG-linked components that can strengthen providers' results frameworks and make them more compatible with and useful for partners' results-based development planning and management.

Table 3 also confirms some challenges and shortcomings of the SDG targets and indicators as components of results frameworks. While the targets (with supporting, robust indicators) are reasonably well spread across the SDGs, there are some obvious challenges:

- SDG 1 on poverty: Given the overriding importance of poverty reduction in development co-operation, the two SDG outcome targets (with two indicators attached, see Annex 3 ) are somewhat limited. Yet, they are about eradication of extreme poverty, broken down by sex, age, employment status and geographical location (urban/rural), which is a prioritised result of practically all providers and partners in development co-operation.

- SDGs 3, 4 and 6 on health, education and water \& sanitation: These "MDG-continuation" SDGs are noteworthy because they have both outcome and $\mathrm{MOI}$ targets and indicators. Depending on the objectives and portfolios of the provider, they are therefore obvious choices for SDG links in providers' results frameworks.

- SDGs $\mathbf{5}$ and $\mathbf{1 0}$ on gender equality and reduced inequalities: These SDGs receive much emphasis in the development co-operation objectives of most providers; yet, the SDG targets that meet the criteria applied here (dealing with outcomes, and with robust indicators) are few and selective (see Annex 3 ). The relevant gender equality indicators relate to women in parliaments and in managerial positions, which fail to address comprehensively gender inequalities. The difficulty objectively and quantitatively to capture these equality objectives has been a continuous challenge to development co-operation.

- SDGs 7-9 on energy, growth and infrastructure: These SDG targets are concrete, and many SDG indicators are robust and informative. The wide scope of the SDG targets and indicators allows providers to focus on those areas, where their development co-operation makes a significant contribution. 
- SDGs 11-15 on sustainable cities, responsible consumption \& production, climate change, and life below water \& on land: These environment and sustainability related SDG targets represent a major advance by the 2030 Agenda over the MDGs. Yet, the few targets listed in Table 3 and Annex 3 also confirm that the international community has yet to develop a clear monitoring framework for sustainability - with the exception of climate change, which is covered under the Paris Convention rather than the 2030 Agenda. The results frameworks of both providers and partners should incorporate targets and indicators from the Paris Convention in addition to the 42 SDG targets and 53 SDG indicators listed in Annex 3.

- SDG 16 on peace, justice and inclusive institutions: The six SDG targets, supported by seven robust indicators, are mostly concerned with the absence of violence and corruption and with effective budget control and birth registration. This is a selective expression of the visions and ambitions of the SDG itself, due to the difficulty of identifying clear outcome targets with robust indicators for a number of human rights and good governance issues.

- SDG 17 on means of implementation and partnerships: Despite the large number of targets (19) under SDG 17, only a few are potentially useful for providers' results frameworks, partly because of the big and diverse issues addressed, partly because of the absence of robust SDG indicators.

To pursue the benefits from incorporating SDG targets and indicators in development co-operation results frameworks, providers have a number of options, covering provider-specific measures and joint efforts with national and international partners. The options for individual providers were discussed in Section 1 on the purposes of using SDG-linked results information. Here, some options are summarised on how key international bodies may use the information gathered through SDG-linked results frameworks:

- With SDG-based progress indicators and development results information, the OECD-DAC can better assess providers' results frameworks in peer reviews, since comparable data will be available. The DAC can include providers' and partners' country-specific results frameworks in its dialogues on the contribution of development co-operation to the achievement of the SDGs, which is firmly within the DAC's mandate. Finally, the approach would support the efforts by WP-STAT (the DAC Working Party on Development Finance Statistics) to link input-data on ODA to outcome data on SDG progress.

- The UN High Level Political Forum and the ECOSOC Development Co-operation Forum can deepen their discussions of the Voluntary National Reviews on SDG policies and progress, including the role of development co-operation. The VNRs address substantive progress and challenges in achieving the SDGs in individual countries, which lifts the debate beyond policies and institutions and potentially focuses on impact and change.

- The Global Partnership for Effective Development Co-operation's $1^{\text {st }}$ and $7^{\text {th }}$ monitoring indicators ("development co-operation is focused on results that meet developing countries' needs" and "mutual accountability among development co-operation actors is strengthened through inclusive reviews") can go beyond issues around the use of systems to address the respective contribution of development actors in achieving the SDGs. 


\section{Linking SDG targets \& indicators with providers' standard indicators}

This section examines whether there is scope to link relevant SDG outcome-based targets and indicators with providers' current standard indicators (at Tiers 1 and 2 of results frameworks). Such an approach can potentially strengthen results frameworks for development and development co-operation as well as streamline, and thus reduce the burden of, data collection and reporting for both providers and partners.

The results frameworks of some providers include standard indicators for measuring the outputs and outcomes of development and development co-operation at Tiers $\mathbf{1}$ and $\mathbf{2}$. Standard indicators at Tier 1 are usually based on country or global level outcome data which providers contribute to through their development co-operation - they report on change at the country level. Standard indicators at Tier 2 are used to aggregate (and in some cases attribute) data based on the direct results of development co-operation. They often report on the number of people reached by an intervention (OECD, 2017b). The following table presents the number of standard indicators used at Tiers 1 and 2 by a selection of eight development cooperation providers known currently to use standard indicators. The indicators cover a range of sectors and are usually organised by thematic focus. In addition, the indicators are often aligned to the SDGs at goal level (for example, Finland, Netherlands, and Switzerland (Swiss Development Cooperation) take this approach). Links to the full indicator sets, where available, are provided in Annex 5.

Table 4: Number of standard indicators at Tiers 1 and 2 for development co-operation providers

\begin{tabular}{|lcc|}
\hline Provider & No. of standard indicators at Tier 1 & No. of standard indicators at Tier 2 \\
\hline European Commission & 32 & 32 \\
\hline Finland & No Tier 1 indicators & 11 \\
\hline Netherlands & No Tier 1 indicators & 15 \\
\hline New Zealand & 40 & 47 \\
\hline Switzerland - SDC & No Tier 1 indicators & 40 \\
\hline United Kingdom - DFID & No Tier 1 indicators & 6 \\
\hline The World Bank Group & 19 & 15 \\
\hline Asian Development Bank & 22 & 30 \\
\hline
\end{tabular}

This selection of eight providers is not intended to be representative of all providers of development cooperation, and other providers either have yet to, or are in the process of developing standard indicators (e.g. Canada), or have chosen not to pursue a results-based management approach which includes standard indicators (e.g. Sweden).

Annex 5 presents findings of a comparative analysis to determine the extent to which there is either a direct match or a relationship (similarity) between SDG targets \& indicators and standard indicators of the agencywide results frameworks of the providers listed in Table 4. The tables presented in Annex 5 are a resource which could be used by DAC and other providers in a number of ways. Firstly, they could help providers that have already established standard indicators to identify opportunities for enhanced links to SDG targets and indicators over time. Secondly, the tables enable providers who are in the process of developing standard indicators to link their frameworks and indicators to the SDGs. Thirdly, they may help providers using standard 
indicators to develop narratives to communicate meaningfully on the contribution of their development cooperation to SDG targets by showing how results from their existing standard indicators contribute toward SDG targets. Finally, and related to all of the above, the tables could be used at country level to enhance links between provider standard indicators and the SDG targets and indicators that developing countries have built into SDG-linked national development plans and related frameworks.

Providers may benefit from taking a step further than just aligning their results frameworks to the SDGs at goals level. They can make concrete efforts directly to link their results framework to the SDG targets and indicators that are focused on outcomes. By doing this they may highlight the contributory relationship between the support (Tier 2 of provider results frameworks) and the SDG targets - and related indicators that their partners have prioritised and plan to measure and report against. Furthermore, providers may also wish collectively to consider harmonising relevant Tier 2 indicators using the SDGs as a shared framework (OECD, 2017c). Overall, more dialogue and analysis is needed to connect the dots between indicators that count beneficiaries reached and indicators which count proportions of population; regardless of whether providers take an attribution or contribution approach, as they often come from the same dataset.

Finally, results frameworks could be further strengthened by also linking to related $\mathrm{MOI}$ indicators. For example, a provider supporting water initiatives might use the indicators given in Table 5 at each of the three Tiers for reporting at corporate and/or country levels.

Table 5: Examples of water-related indicators

\begin{tabular}{|ll|}
\hline $\begin{array}{l}\text { Provider results framework tier } 1 \text { development } \\
\text { results }\end{array}$ & $\begin{array}{l}\text { Examples of indicators } \\
\text { 6.1.1. Proportion of population using safely managed drinking water } \\
\text { service - by country/region }\end{array}$ \\
\hline $\begin{array}{l}\text { Tier 2: development } \\
\text { co-operation results }\end{array}$ & $\begin{array}{l}\text { Provider standard indicator: Number of people with sustainable access } \\
\text { to clean water ( } \mathrm{m} / \mathrm{f}+\text { other relevant disaggregation) } \\
\text { (Subset of data at Tier } 1 \text { - in relevant regions, countries, districts where } \\
\text { provider is delivering support) }\end{array}$ \\
\hline $\begin{array}{l}\text { Tier 3: performance } \\
\text { information }\end{array}$ & $\begin{array}{l}\text { 6.a.1. Amount of water and sanitation-related official development } \\
\text { assistance that is part of a government co-ordinated spending plan - by } \\
\text { country, and for provider as a whole }\end{array}$ \\
\hline
\end{tabular}

Adopting an approach similar to the example above, for this or other indicators, strengthens the results chain, and makes explicit a provider's contribution to the SDGs and partner priorities, in a tangible and meaningful way. Perhaps most importantly it shows there is scope to reduce the burden of collecting special-purpose data needed for standard indicators. In addition, for the majority of providers that do not have such distinct standard indicators in their results frameworks, the SDG-linked results indicators will present good opportunities for cost-effective results monitoring. The challenge is to ensure that providers' needs vis-à-vis domestic/corporate use of results information is also being met. 


\section{Annex 1: Definitions of results frameworks and approaches}

The results chain has been used in development co-operation for decades, drawing from DAC's evaluation guidelines. The tiers of results frameworks, building upon early work by the UK's DFID and the World Bank, are less authoritative, because providers have changing needs. The following understanding of results frameworks and related concepts is used in the analytical work of the DCD Results Team.

RESULTS FRAMEWORKS

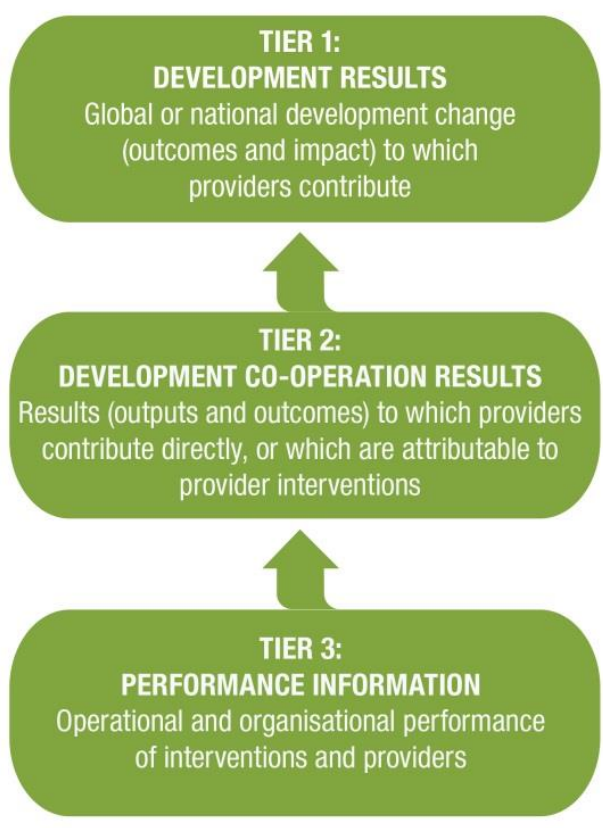

RESULTS CHAIN

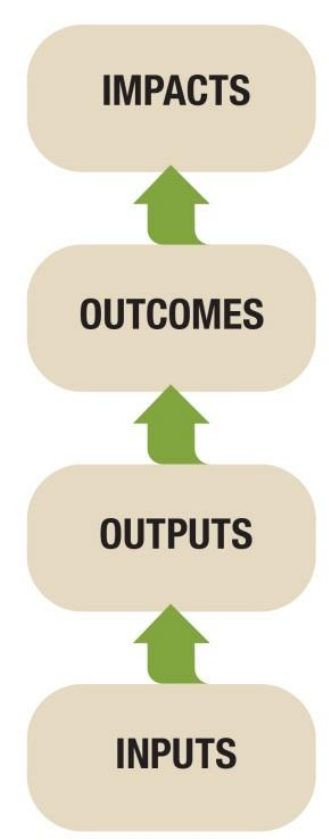

\begin{tabular}{|c|c|}
\hline Term & Proposed definitions for providers of development co-operation \\
\hline $\begin{array}{l}\text { Results } \\
\text { framework }\end{array}$ & $\begin{array}{l}\text { A management, planning and reporting tool that sets out goals, priorities and expected results (outputs, } \\
\text { outcomes, impacts) for a provider's development co-operation policies, programmes and budgets. The results } \\
\text { framework includes the underlying logic (theory of change) of how results will be achieved from inputs to } \\
\text { outputs, outcomes and impacts, and describes how they will be measured and monitored. }\end{array}$ \\
\hline Results & $\begin{array}{l}\text { The approach a development co-operation agency or provider takes to embed results-based management - } \\
\text { often articulated through a results strategy / theory of change / purpose statement. It articulates how results } \\
\text { information is collected and used at different levels and for what purpose. }\end{array}$ \\
\hline $\begin{array}{l}\text { Provider- } \\
\text { specific country } \\
\text { results } \\
\text { framework }\end{array}$ & $\begin{array}{l}\text { A management tool that articulates the objectives for development co-operation in a partner country, the } \\
\text { underlying logic of how they will be achieved from inputs to outcomes and impacts, and how they will be } \\
\text { measured. It can include trade and foreign policy objectives, and is typically aligned to the provider's results } \\
\text { framework and the partner's national development plan and/or country results framework. }\end{array}$ \\
\hline $\begin{array}{l}\text { Standard } \\
\text { indicator set }\end{array}$ & $\begin{array}{l}\text { A standardised set of indicators used by development co-operation providers to monitor results. They are } \\
\text { typically used for three tiers of results frameworks: (1) development results; (2) development co-operation } \\
\text { results; (3) performance information. Standard indicators at Tier } 2 \text { typically aggregate project-level results in a } \\
\text { way which enables communication of results achieved across multiple projects, countries and regions. }\end{array}$ \\
\hline $\begin{array}{l}\text { Memo } \\
\text { definition: } \\
\text { Country-led } \\
\text { results } \\
\text { framework }\end{array}$ & $\begin{array}{l}\text { "A country-led results framework is led or originated by the government of the country itself. This can include } \\
\text { any form of government-led planning instrument that defines a country's approach to development, sets out } \\
\text { its development priorities and establishes the results expected to be achieved. It also outlines the systems and } \\
\text { tools that will be used to monitor and evaluate progress towards these targets, establishes the indicators of } \\
\text { progress and determines the baseline against which results will be measured." (OECD/UNDP, 2016: 44) }\end{array}$ \\
\hline
\end{tabular}




\section{Annex 2: Outcome-oriented SDG targets}

The analysis of the Results Team suggests that 89 of the 169 SDG targets focus on outcome change by the given deadline (usually 2030). The ones not included are a) the 43 targets under SDGs 1-16 that are "means of implementation" targets; b) the 19 targets under SDG17 that are all about means of implementation; and c) 18 SDG targets assessed for this analysis to have a primary focus on processes and institutions.

\section{Goal 1. End poverty in all its forms everywhere}

1.1 By 2030, eradicate extreme poverty for all people everywhere, currently measured as people living on less than $\$ 1.25$ a day

1.2

By 2030, reduce at least by half the proportion of men, women and children of all ages living in poverty in all its dimensions according to national definitions

1.3 Implement nationally appropriate social protection systems and measures for all, including floors, and by 2030 achieve substantial coverage of the poor and the vulnerable

By 2030, ensure that all men and women, in particular the poor and the vulnerable, have equal rights to

1.4 economic resources, as well as access to basic services, ownership and control over land and other forms of property, inheritance, natural resources, appropriate new technology and financial services, including microfinance

By 2030, build the resilience of the poor and those in vulnerable situations and reduce their exposure and

1.5 vulnerability to climate-related extreme events and other economic, social and environmental shocks and disasters

Goal 2. End hunger, achieve food security and improved nutrition and promote sustainable agriculture

2.1

By 2030, end hunger and ensure access by all people, in particular the poor and people in vulnerable situations, including infants, to safe, nutritious and sufficient food all year round

2.2 stunting and wasting in children under 5 years of age, and address the nutritional needs of adolescent girls, pregnant and lactating women and older persons

By 2030, double the agricultural productivity and incomes of small-scale food producers, in particular women, indigenous peoples, family farmers, pastoralists and fishers, including through secure and equal access to land, other productive resources and inputs, knowledge, financial services, markets and opportunities for value addition and non-farm employment

By 2030, ensure sustainable food production systems and implement resilient agricultural practices that increase productivity and production, that help maintain ecosystems, that strengthen capacity for adaptation to climate change, extreme weather, drought, flooding and other disasters and that progressively improve land and soil quality

By 2020, maintain the genetic diversity of seeds, cultivated plants and farmed and domesticated animals and their related wild species, including through soundly managed and diversified seed and plant banks at the

2.5 national, regional and international levels, and promote access to and fair and equitable sharing of benefits arising from the utilization of genetic resources and associated traditional knowledge, as internationally agreed

Goal 3. Ensure healthy lives and promote well-being for all at all ages as 25 per 1,000 live births 
By 2030, reduce by one third premature mortality from non-communicable diseases through prevention and treatment and promote mental health and well-being

\begin{tabular}{|c|l|}
3.5 & $\begin{array}{l}\text { Strengthen the prevention and treatment of substance abuse, including narcotic drug abuse and harmful use } \\
\text { of alcohol }\end{array}$ \\
\hline 3.6 & By 2020, halve the number of global deaths and injuries from road traffic accidents \\
\hline 3.7 & $\begin{array}{l}\text { By 2030, ensure universal access to sexual and reproductive health-care services, including for family planning, } \\
\text { information and education, and the integration of reproductive health into national strategies and } \\
\text { programmes }\end{array}$ \\
\hline 3.8 & $\begin{array}{l}\text { Achieve universal health coverage, including financial risk protection, access to quality essential health-care } \\
\text { services and access to safe, effective, quality and affordable essential medicines and vaccines for all }\end{array}$ \\
\hline 3.9 & $\begin{array}{l}\text { By 2030, substantially reduce the number of deaths and illnesses from hazardous chemicals and air, water and } \\
\text { soil pollution and contamination }\end{array}$
\end{tabular}

Goal 4. Ensure inclusive and equitable quality education and promote lifelong learning opportunities for all

\begin{tabular}{|c|l|}
\hline 4.1 & $\begin{array}{l}\text { By 2030, ensure that all girls and boys complete free, equitable and quality primary and secondary education } \\
\text { leading to relevant and effective learning outcomes }\end{array}$ \\
\hline 4.2 & $\begin{array}{l}\text { By 2030, ensure that all girls and boys have access to quality early childhood development, care and pre- } \\
\text { primary education so that they are ready for primary education }\end{array}$ \\
\hline 4.3 & $\begin{array}{l}\text { By 2030, ensure equal access for all women and men to affordable and quality technical, vocational and } \\
\text { tertiary education, including university }\end{array}$ \\
\hline 4.4 & $\begin{array}{l}\text { By 2030, substantially increase the number of youth and adults who have relevant skills, including technical } \\
\text { and vocational skills, for employment, decent jobs and entrepreneurship }\end{array}$ \\
\hline 4.5 & $\begin{array}{l}\text { By 2030, eliminate gender disparities in education and ensure equal access to all levels of education and } \\
\text { vocational training for the vulnerable, including persons with disabilities, indigenous peoples and children in } \\
\text { vulnerable situations }\end{array}$ \\
\hline 4.6 & $\begin{array}{l}\text { By 2030, ensure that all youth and a substantial proportion of adults, both men and women, achieve literacy } \\
\text { and numeracy }\end{array}$ \\
\hline 4.7 & $\begin{array}{l}\text { By 2030, ensure that all learners acquire the knowledge and skills needed to promote sustainable } \\
\text { development, including, among others, through education for sustainable development and sustainable } \\
\text { lifestyles, human rights, gender equality, promotion of a culture of peace and non-violence, global citizenship } \\
\text { and appreciation of cultural diversity and of culture's contribution to sustainable development }\end{array}$ \\
\hline
\end{tabular}

Goal 5. Achieve gender equality and empower all women and girls

5.1 End all forms of discrimination against all women and girls everywhere

5.2 Eliminate all forms of violence against all women and girls in the public and private spheres, including trafficking and sexual and other types of exploitation

5.3 Eliminate all harmful practices, such as child, early and forced marriage and female genital mutilation

5.4 Recognize and value unpaid care and domestic work through the provision of public services, infrastructure and social protection policies and the promotion of shared responsibility within the household and the family as nationally appropriate

5.5

Ensure women's full and effective participation and equal opportunities for leadership at all levels of decisionmaking in political, economic and public life

Ensure universal access to sexual and reproductive health and reproductive rights as agreed in accordance

5.6 with the Programme of Action of the International Conference on Population and Development and the Beijing Platform for Action and the outcome documents of their review conferences

Goal 6. Ensure availability and sustainable management of water and sanitation for all

6.1 By 2030, achieve universal and equitable access to safe and affordable drinking water for all 
By 2030, achieve access to adequate and equitable sanitation and hygiene for all and end open defecation, paying special attention to the needs of women and girls and those in vulnerable situations

By 2030, improve water quality by reducing pollution, eliminating dumping and minimizing release of

6.3 hazardous chemicals and materials, halving the proportion of untreated wastewater and substantially increasing recycling and safe reuse globally

6.4

By 2030 , substantially increase water-use efficiency across all sectors and ensure sustainable withdrawals and supply of freshwater to address water scarcity and substantially reduce the number of people suffering from water scarcity

6.6

By 2020, protect and restore water-related ecosystems, including mountains, forests, wetlands, rivers, aquifers and lakes

Goal 7. Ensure access to affordable, reliable, sustainable and modern energy for all

7.1

By 2030, ensure universal access to affordable, reliable and modern energy services

7.2 By 2030 , increase substantially the share of renewable energy in the global energy mix

7.3

By 2030, double the global rate of improvement in energy efficiency

Goal 8. Promote sustained, inclusive and sustainable economic growth, full and productive employment and decent work for all

8.1

Sustain per capita economic growth in accordance with national circumstances and, in particular, at least 7 per cent gross domestic product growth per annum in the least developed countries

8.2

Achieve higher levels of economic productivity through diversification, technological upgrading and

innovation, including through a focus on high-value added and labour-intensive sectors

Improve progressively, through 2030, global resource efficiency in consumption and production and endeavour to decouple economic growth from environmental degradation, in accordance with the 10-Year Framework of Programmes on Sustainable Consumption and Production, with developed countries taking the lead

8.5

By 2030, achieve full and productive employment and decent work for all women and men, including for young people and persons with disabilities, and equal pay for work of equal value

8.6 By 2020, substantially reduce the proportion of youth not in employment, education or training

Take immediate and effective measures to eradicate forced labour, end modern slavery and human trafficking

8.7 and secure the prohibition and elimination of the worst forms of child labour, including recruitment and use of child soldiers, and by 2025 end child labour in all its forms

8.8 Protect labour rights and promote safe and secure working environments for all workers, including migrant workers, in particular women migrants, and those in precarious employment

Goal 9. Build resilient infrastructure, promote inclusive and sustainable industrialization and foster innovation

9.2

Promote inclusive and sustainable industrialization and, by 2030, significantly raise industry's share of employment and gross domestic product, in line with national circumstances, and double its share in least developed countries

By 2030, upgrade infrastructure and retrofit industries to make them sustainable, with increased resource-use efficiency and greater adoption of clean and environmentally sound technologies and industrial processes, with all countries taking action in accordance with their respective capabilities

Enhance scientific research, upgrade the technological capabilities of industrial sectors in all countries, in particular developing countries, including, by 2030, encouraging innovation and substantially increasing the number of research and development workers per 1 million people and public and private research and development spending 
10.1 By 2030, progressively achieve and sustain income growth of the bottom 40 per cent of the population at a rate higher than the national average

10.2 By 2030, empower and promote the social, economic and political inclusion of all, irrespective of age, sex, disability, race, ethnicity, origin, religion or economic or other status

10.3 Ensure equal opportunity and reduce inequalities of outcome, including by eliminating discriminatory laws, policies and practices and promoting appropriate legislation, policies and action in this regard

10.4 Adopt policies, especially fiscal, wage and social protection policies, and progressively achieve greater equality

10.7 Facilitate orderly, safe, regular and responsible migration and mobility of people, including through the implementation of planned and well-managed migration policies

Goal 11. Make cities and human settlements inclusive, safe, resilient and sustainable

11.1 By 2030, ensure access for all to adequate, safe and affordable housing and basic services and upgrade slums By 2030, provide access to safe, affordable, accessible and sustainable transport systems for all, improving

11.2 road safety, notably by expanding public transport, with special attention to the needs of those in vulnerable situations, women, children, persons with disabilities and older persons

By 2030, significantly reduce the number of deaths and the number of people affected and substantially 11.5 decrease the direct economic losses relative to global gross domestic product caused by disasters, including water-related disasters, with a focus on protecting the poor and people in vulnerable situations

By 2030, reduce the adverse per capita environmental impact of cities, including by paying special attention to air quality and municipal and other waste management

By 2030, provide universal access to safe, inclusive and accessible, green and public spaces, in particular for women and children, older persons and persons with disabilities

\section{Goal 12. Ensure sustainable consumption and production patterns}

12.2 By 2030, achieve the sustainable management and efficient use of natural resources

12.3 By 2030, halve per capita global food waste at the retail and consumer levels and reduce food losses along production and supply chains, including post-harvest losses

By 2020, achieve the environmentally sound management of chemicals and all wastes throughout their life

12.4 cycle, in accordance with agreed international frameworks, and significantly reduce their release to air, water and soil in order to minimize their adverse impacts on human health and the environment

12.5 By 2030, substantially reduce waste generation through prevention, reduction, recycling and reuse

\section{Goal 13. Take urgent action to combat climate change and its impacts}

Reduce greenhouse gas emissions, in line with long term goal of achieving net zero global emissions between 2050 and 2100

13.1 Strengthen resilience and adaptive capacity to climate-related hazards and natural disasters in all countries Improve education, awareness-raising and human and institutional capacity on climate change mitigation, adaptation, impact reduction and early warning

Goal 14. Conserve and sustainably use the oceans, seas and marine resources for sustainable development

14.1 By 2025, prevent and significantly reduce marine pollution of all kinds, in particular from land-based activities, including marine debris and nutrient pollution

By 2020, sustainably manage and protect marine and coastal ecosystems to avoid significant adverse impacts,

14.2 including by strengthening their resilience, and take action for their restoration in order to achieve healthy and productive oceans

14.3 Minimize and address the impacts of ocean acidification, including through enhanced scientific cooperation at all levels 
By 2020, effectively regulate harvesting and end overfishing, illegal, unreported and unregulated fishing and destructive fishing practices and implement science-based management plans, in order to restore fish stocks in the shortest time feasible, at least to levels that can produce maximum sustainable yield as determined by their biological characteristics

By 2020, conserve at least 10 per cent of coastal and marine areas, consistent with national and international law and based on the best available scientific information

By 2030, increase the economic benefits to small island developing States and least developed countries from

14.7 the sustainable use of marine resources, including through sustainable management of fisheries, aquaculture and tourism

Goal 15. Protect, restore and promote sustainable use of terrestrial ecosystems, sustainably manage forests, combat desertification, and halt and reverse land degradation and halt biodiversity loss

By 2020, ensure the conservation, restoration and sustainable use of terrestrial and inland freshwater

15.1 ecosystems and their services, in particular forests, wetlands, mountains and drylands, in line with obligations under international agreements

15.2

By 2020, promote the implementation of sustainable management of all types of forests, halt deforestation, restore degraded forests and substantially increase afforestation and reforestation globally

15.3 By 2030, combat desertification, restore degraded land and soil, including land affected by desertification, drought and floods, and strive to achieve a land degradation-neutral world

15.4 By 2030, ensure the conservation of mountain ecosystems, including their biodiversity, in order to enhance their capacity to provide benefits that are essential for sustainable development

15.5 Take urgent and significant action to reduce the degradation of natural habitats, halt the loss of biodiversity and, by 2020, protect and prevent the extinction of threatened species

Promote fair and equitable sharing of the benefits arising from the utilization of genetic resources and promote appropriate access to such resources, as internationally agreed

15.7

Take urgent action to end poaching and trafficking of protected species of flora and fauna and address both demand and supply of illegal wildlife products

Goal 16. Promote peaceful and inclusive societies for sustainable development, provide access to justice for all and build effective, accountable and inclusive institutions at all levels

16.1 Significantly reduce all forms of violence and related death rates everywhere

16.2 End abuse, exploitation, trafficking and all forms of violence against and torture of children

16.3 Promote the rule of law at the national and international levels and ensure equal access to justice for all

16.4 By 2030, significantly reduce illicit financial and arms flows, strengthen the recovery and return of stolen assets and combat all forms of organized crime

16.5 Substantially reduce corruption and bribery in all their forms

16.6 Develop effective, accountable and transparent institutions at all levels

16.7 Ensure responsive, inclusive, participatory and representative decision-making at all levels

16.9 By 2030, provide legal identity for all, including birth registration

16.10

Ensure public access to information and protect fundamental freedoms, in accordance with national legislation and international agreements

Goal 17. Strengthen the means of implementation and revitalize the Global Partnership for Sustainable Development 


\section{Annex 3: SDG outcome targets supported by robust / tier one SDG indicators}

The table below lists those SDG outcome targets (from Annex 2) that are also supported by robust / tier one SDG indicators. The list comprises 42 SDG outcome targets supported by 53 robust SDG indicators. (UNStat, 2017)

\section{Goal 1. End poverty in all its forms everywhere}

By 2030, eradicate extreme poverty for all people everywhere, currently measured as people living on less

1.1 than $\$ 1.25$ a day:

1.1.1 Proportion of population below the international poverty line, by sex, age, employment status and geographical location (urban/rural)

By 2030, reduce at least by half the proportion of men, women and children of all ages living in poverty in all

1.2 its dimensions according to national definitions:

1.2.1 Proportion of population living below the national poverty line, by sex and age

Goal 2. End hunger, achieve food security and improved nutrition and promote sustainable

agriculture

By 2030, end hunger and ensure access by all people, in particular the poor and people in vulnerable situations, including infants, to safe, nutritious and sufficient food all year round:

2.1 2.1.1 Prevalence of undernourishment

2.1.2 Prevalence of moderate or severe food insecurity in the population, based on the Food Insecurity Experience Scale (FIES)

By 2030, end all forms of malnutrition, including achieving, by 2025, the internationally agreed targets on stunting and wasting in children under 5 years of age, and address the nutritional needs of adolescent girls, pregnant and lactating women and older persons:

2.2 2.2.1 Prevalence of stunting (height for age $<-2$ standard deviation from the median of the World Health Organization (WHO) Child Growth Standards) among children under 5 years of age

2.2.2 Prevalence of malnutrition (weight for height $>+2$ or $<-2$ standard deviation from the median of the WHO Child Growth Standards) among children under 5 years of age, by type (wasting and overweight)

Goal 3. Ensure healthy lives and promote well-being for all at all ages

3.1

By 2030, reduce the global maternal mortality ratio to less than 70 per 100,000 live births:

3.1.2 Proportion of births attended by skilled health personnel

By 2030, end preventable deaths of new-borns and children under 5 years of age, with all countries aiming to reduce neonatal mortality to at least as low as 12 per 1,000 live births and under-5 mortality to at least as

3.2 low as 25 per 1,000 live births:

3.2.1 Under-five mortality rate

3.2.2 Neonatal mortality rate

By 2030, end the epidemics of AIDS, tuberculosis, malaria and neglected tropical diseases and combat hepatitis, water-borne diseases and other communicable diseases:

3.3 3.3.2 Tuberculosis incidence per 100,000 population

3.3.3 Malaria incidence per 1,000 population

3.3.5 Number of people requiring interventions against neglected tropical diseases

Strengthen the prevention and treatment of substance abuse, including narcotic drug abuse and harmful use

3.5 of alcohol:

3.5.2 Harmful use of alcohol, defined according to the national context as alcohol per capita consumption (aged 15 years and older) within a calendar year in litres of pure alcohol

3.6

By 2020, halve the number of global deaths and injuries from road traffic accidents:

3.6.1 Death rate due to road traffic injuries

By 2030, ensure universal access to sexual and reproductive health-care services, including for family planning, information and education, and the integration of reproductive health into national strategies and 3.7 programmes:

3.7.1 Proportion of women of reproductive age (aged 15-49 years) who have their need for family planning satisfied with modern methods 
By 2030, substantially reduce the number of deaths and illnesses from hazardous chemicals and air, water and soil pollution and contamination:

3.9.1 Mortality rate attributed to household and ambient air pollution

Goal 4. Ensure inclusive and equitable quality education and promote lifelong learning

opportunities for all

4.2

By 2030, ensure that all girls and boys have access to quality early childhood development, care and preprimary education so that they are ready for primary education:

4.2.2 Participation rate in organized learning (one year before the official primary entry age), by sex By 2030, eliminate gender disparities in education and ensure equal access to all levels of education and vocational training for the vulnerable, including persons with disabilities, indigenous peoples and children in $4.5 \quad$ vulnerable situations:

4.5.1 Parity indices (female/male, rural/urban, bottom/top wealth quintile and others such as disability status, indigenous peoples and conflict-affected, as data become available) for all education indicators on this list that can be disaggregated

\section{Goal 5. Achieve gender equality and empower all women and girls}

Ensure women's full and effective participation and equal opportunities for leadership at all levels of

5.5 decision-making in political, economic and public life:

5.5.1 Proportion of seats held by women in (a) national parliaments and (b) local governments 5.5.2 Proportion of women in managerial positions

\section{Goal 6. Ensure availability and sustainable management of water and sanitation for all}

6.1

6.2

By 2030, achieve universal and equitable access to safe and affordable drinking water for all:

6.1.1 Proportion of population using safely managed drinking water service

By 2030, achieve access to adequate and equitable sanitation and hygiene for all and end open defecation, paying special attention to the needs of women and girls and those in vulnerable situations:

6.2.1 Proportion of population using safely managed sanitation services, including a hand-washing facility with soap and water

Goal 7. Ensure access to affordable, reliable, sustainable and modern energy for all

By 2030, ensure universal access to affordable, reliable and modern energy services:

7.1 7.1.1 Proportion of population with access to electricity

7.1.2 Proportion of population with primary reliance on clean fuels and technology

7.2 By 2030, increase substantially the share of renewable energy in the global energy mix:

7.2.1 Renewable energy share in the total final energy consumption

7.3

By 2030, double the global rate of improvement in energy efficiency:

7.3.1 Energy intensity measured in terms of primary energy and GDP

Goal 8. Promote sustained, inclusive and sustainable economic growth, full and productive employment and decent work for all

Sustain per capita economic growth in accordance with national circumstances and, in particular, at least 7

8.1 per cent gross domestic product growth per annum in the least developed countries:

8.1.1 Annual growth rate of real GDP per capita

Achieve higher levels of economic productivity through diversification, technological upgrading and

8.2 innovation, including through a focus on high-value added and labour-intensive sectors:

8.2.1 Annual growth rate of real GDP per employed person

By 2030, achieve full and productive employment and decent work for all women and men, including for

8.5 young people and persons with disabilities, and equal pay for work of equal value:

8.5.2 Unemployment rate, by sex, age and persons with disabilities

8.6

By 2020, substantially reduce the proportion of youth not in employment, education or training:

8.6.1 Proportion of youth (aged 15-24 years) not in education, employment or training

Take immediate and effective measures to eradicate forced labour, end modern slavery and human

8.7 trafficking and secure the prohibition and elimination of the worst forms of child labour, including recruitment and use of child soldiers, and by 2025 end child labour in all its forms:

8.7.1 Proportion and number of children aged 5-17 years engaged in child labour, by sex and age 
Protect labour rights and promote safe and secure working environments for all workers, including migrant workers, in particular women migrants, and those in precarious employment:

8.8.1 Frequency rates of fatal and non-fatal occupational injuries, by sex and migrant status

Goal 9. Build resilient infrastructure, promote inclusive and sustainable industrialization and foster innovation

Promote inclusive and sustainable industrialization and, by 2030, significantly raise industry's share of employment and gross domestic product, in line with national circumstances, and double its share in least

9.2 developed countries:

9.2.1 Manufacturing value added as a proportion of GDP and per capita

9.2.2 Manufacturing employment as a proportion of total employment

By 2030, upgrade infrastructure and retrofit industries to make them sustainable, with increased resource-

9.4 use efficiency and greater adoption of clean and environmentally sound technologies and industrial processes, with all countries taking action in accordance with their respective capabilities:

9.4.1 CO2 emission per unit of value added

Enhance scientific research, upgrade the technological capabilities of industrial sectors in all countries, in particular developing countries, including, by 2030, encouraging innovation and substantially increasing the

9.5 number of research and development workers per 1 million people and public and private research and development spending:

9.5.1 Research and development expenditure as a proportion of GDP

9.5.2 Researchers (in full-time equivalent) per million inhabitants

Goal 10. Reduce inequality within and among countries

By 2030, progressively achieve and sustain income growth of the bottom 40 per cent of the population at a

10.1 rate higher than the national average:

10.1.1 Growth rates of household expenditure or income per capita among the bottom 40 per cent of the population and the total population

Adopt policies, especially fiscal, wage and social protection policies, and progressively achieve greater

10.4 equality:

10.4.1 Labour share of GDP, comprising wages and social protection transfers

Goal 11. Make cities and human settlements inclusive, safe, resilient and sustainable

11.1 slums:

11.1.1 Proportion of urban population living in slums, informal settlements or inadequate housing By 2030, reduce the adverse per capita environmental impact of cities, including by paying special attention

11.6 to air quality and municipal and other waste management:

11.6.2 Annual mean levels of fine particulate matter (e.g. PM2.5 and PM10) in cities (population weighted)

\section{Goal 12. Ensure sustainable consumption and production patterns}

By 2020, achieve the environmentally sound management of chemicals and all wastes throughout their life cycle, in accordance with agreed international frameworks, and significantly reduce their release to air, water and soil in order to minimize their adverse impacts on human health and the environment:

12.4.1 Number of parties to international multilateral environmental agreements on hazardous waste, and other chemicals that meet their commitments and obligations in transmitting information as required by each relevant agreement

\section{Goal 13. Take urgent action to combat climate change and its impacts}

Goal 14. Conserve and sustainably use the oceans, seas and marine resources for sustainable development

By 2020, effectively regulate harvesting and end overfishing, illegal, unreported and unregulated fishing and destructive fishing practices and implement science-based management plans, in order to restore fish stocks

14.4 in the shortest time feasible, at least to levels that can produce maximum sustainable yield as determined by their biological characteristics:

14.4.1 Proportion of fish stocks within biologically sustainable levels 
By 2020, conserve at least 10 per cent of coastal and marine areas, consistent with national and international law and based on the best available scientific information:

14.5.1 Coverage of protected areas in relation to marine areas

Goal 15. Protect, restore and promote sustainable use of terrestrial ecosystems, sustainably manage forests, combat desertification, and halt and reverse land degradation and halt biodiversity loss

By 2020, ensure the conservation, restoration and sustainable use of terrestrial and inland freshwater ecosystems and their services, in particular forests, wetlands, mountains and drylands, in line with

15.1 obligations under international agreements:

15.1.1 Forest area as a proportion of total land area

15.1.2 Proportion of important sites for terrestrial and freshwater biodiversity that are covered by protected areas, by ecosystem type

Goal 16. Promote peaceful and inclusive societies for sustainable development, provide access to justice for all and build effective, accountable and inclusive institutions at all levels

16.1

Significantly reduce all forms of violence and related death rates everywhere:

16.1.1 Number of victims of intentional homicide per 100,000 population, by sex and age

End abuse, exploitation, trafficking and all forms of violence against and torture of children:

16.2 16.2.1 Proportion of children aged 1-17 years who experienced any physical punishment and/or psychological aggression by caregivers in the past month 16.2.2 Number of victims of human trafficking per 100,000 population, by sex, age and form of exploitation

16.3

Promote the rule of law at the national and international levels and ensure equal access to justice for all: 16.3.2 Unsentenced detainees as a proportion of overall prison population

16.5 16.5.2 Proportion of businesses that had at least one contact with a public official and that paid a bribe to a public official, or were asked for a bribe by those public officials during the previous 12 months Develop effective, accountable and transparent institutions at all levels:

16.6 16.6.1 Primary government expenditures as a proportion of original approved budget, by sector (or by budget codes or similar)

By 2030, provide legal identity for all, including birth registration:

16.9 16.9.1 Proportion of children under 5 years of age whose births have been registered with a civil authority, by age

Goal 17. Strengthen the means of implementation and revitalize the Global Partnership for Sustainable Development 


\title{
Annex 4: SDG targets and indicators for provider performance: "Means of implementation" in the 2030 Agenda
}

The table below lists all $\mathrm{MOI}$ targets and related indicators which:

- Are assessed as directly relevant to development co-operation

- Have robust / tier one indicators attached

Table: SDG MOI targets and indicators relevant to development co-operation (UNStat, 2017)

\author{
SDG Target \\ SDG Indicator
}

Goal 2. End hunger, achieve food security and improved nutrition and promote sustainable agriculture

2.a Increase investment, including through enhanced international cooperation, in rural infrastructure, agricultural research and extension services, technology development and plant and livestock gene banks in order to enhance agricultural productive capacity in developing countries, in particular least 2.a.2 Total official flows (official development assistance plus other official flows) to the agriculture sector developed countries

Goal 3. Ensure healthy lives and promote well-being for all at all ages

3.b. Support the research and development of vaccines and medicines for the communicable and non-communicable diseases that primarily affect developing countries, provide access to affordable essential medicines and vaccines, in accordance with the Doha Declaration on the TRIPS Agreement and Public Health, which affirms the right of developing countries to use to the full the provisions in the Agreement on Trade-Related Aspects of Intellectual Property Rights regarding flexibilities to protect public health, and, in particular, provide access to medicines for all

3.c. Substantially increase health financing and the recruitment, development, training and retention of the health workforce in developing countries, especially in least developed countries and small island developing States

Goal 4. Ensure inclusive and equitable quality education and promote lifelong learning opportunities for all

4.a.1 Proportion of schools with access to: (a) electricity; (b) the Internet for pedagogical purposes;

4.a Build and upgrade education facilities that are child, disability and gender sensitive and provide safe, non-violent, inclusive and effective learning environments for all

4.b By 2020, substantially expand globally the number of scholarships available to developing countries, in particular least developed countries, small island developing States and African countries, for enrolment in higher education, including vocational training and information and communications technology, technical, engineering and scientific programmes, in developed countries and other developing countries 3.b.2. Total net official development assistance to medical research and basic health sectors

3.c.1. Health worker density and distribution (potential Tier 2 provider indicator) (c) computers for pedagogical purposes; (d) adapted infrastructure and materials for students with disabilities; (e) basic drinking water; ( $f$ ) single-sex basic sanitation facilities; and (g) basic handwashing facilities (as per the WASH indicator definitions) (potential Tier 2 provider indicator)

4.b.1 Volume of official development assistance flows for scholarships by sector and type of study 
4.c By 2030, substantially increase the supply of qualified teachers, including through international cooperation for teacher training in developing countries, especially least developed countries and small island developing States 4.c.1 Proportion of teachers in: (a) preprimary; (b) primary; (c) lower secondary; and (d) upper secondary education who have received at least the minimum organized teacher training (e.g. pedagogical training) pre-service or inservice required for teaching at the relevant level in a given country (potential Tier 2 provider indicator)

Goal 6. Ensure availability and sustainable management of water and sanitation for all

6.a By 2030, expand international cooperation and capacitybuilding support to developing countries in water- and sanitation-related activities and programmes, including water harvesting, desalination, water efficiency, wastewater treatment, recycling and reuse technologies

6.b Support and strengthen the participation of local communities in improving water and sanitation management

6.a.1. Amount of water- and sanitation related official development assistance that is part of a governmentcoordinated spending plan

6.b.1. Proportion of local administrative units with established and operational policies and procedures for participation of local communities in water and sanitation management (potential Tier 2 provider indicator)

Goal 8. Promote sustained, inclusive and sustainable economic growth, full and productive employment and decent work for all

8.a Increase Aid for Trade support for developing countries, in particular least developed countries, including through the Enhanced Integrated Framework for Trade-related Technical Assistance to Least Developed Countries

Goal 9. Build resilient infrastructure, promote inclusive and sustainable industrialization and foster innovation

9.a Facilitate sustainable and resilient infrastructure development in developing countries through enhanced financial, technological and technical support to African countries, least developed countries, landlocked developing countries and small island developing States

9.c Significantly increase access to information and communications technology and strive to provide universal and affordable access to the Internet in least developed countries by 2020 8.a.1 Aid for Trade commitments and disbursements

Goal 10. Reduce inequality within and among countries

10.b Encourage official development assistance and financial flows, including foreign direct investment, to States where the need is greatest, in particular least developed countries, African countries, small island developing States and landlocked developing countries, in accordance with their national plans and programmes

Goal 15. Protect, restore and promote sustainable use of terrestrial ecosystems, sustainably manage forests, combat desertification, and halt and reverse land degradation and halt biodiversity loss

15.b Mobilize significant resources from all sources and at all levels to finance sustainable forest management and provide adequate incentives to developing countries to advance such management, including for conservation and reforestation
10.b.1Total resource flows for development, by recipient and donor countries and type of flow (e.g. official development assistance, foreign direct investment and other flows) 15.b.1 Official development assistance [and public expenditure] on conservation and sustainable use of biodiversity and ecosystems 9.a.1 Total official international support (official development assistance plus other official flows) to infrastructure

9.c.1 Proportion of population covered by a mobile network, by technology (potential Tier 2 provider indicator) 
Goal 16. Promote peaceful and inclusive societies for sustainable development, provide access to justice for all and build effective, accountable and inclusive institutions at all levels

16.a Strengthen relevant national institutions, including through international cooperation, for building capacity at all levels, in particular in developing countries, to prevent violence and combat terrorism and crime

Goal 17. Reduce inequality within and among countries

\subsection{Strengthen domestic resource mobilization, including} through international support to developing countries, to improve domestic capacity for tax and other revenue collection 17.2 Developed countries to implement fully their official development assistance commitments, including the commitment by many developed countries to achieve the target of 0.7 per cent of gross national income for official development assistance (ODA/GNI) to developing countries and 0.15 to 0.20 per cent of ODA/GNI to least developed countries; ODA providers are encouraged to consider setting a target to provide at least 0.20 per cent of ODA/GNI to least developed countries

17.9 Enhance international support for implementing effective and targeted capacity building in developing countries to support national plans to implement all the Sustainable Development Goals, including through North-South, SouthSouth and triangular cooperation

17.19 By 2030, build on existing initiatives to develop measurements of progress on sustainable development that complement gross domestic product, and support statistical capacity-building in developing countries 16.a.1 Existence of independent national human rights institutions in compliance with the Paris Principles (potential Tier 2 provider indicator)

17.1.1 Total government revenue as a proportion of GDP, by source (potential Tier 2 provider indicator)

17.2.1 Net official development assistance, total and to least developed countries, as a proportion of the Organization for Economic Cooperation and Development (OECD) Development Assistance Committee donors' gross national income (GNI)

17.9.1 Dollar value of financial and technical assistance (including through North-South, SouthSouth and triangular cooperation) committed

17.19.1 Dollar value of all resources made available to strengthen statistical capacity in developing countries 


\section{Annex 5: Comparative analysis of selected SDG targets \& indicators and providers' standard indicators}

The providers of development co-operation covered in this comparative analysis are: the European Commission; Finland; Netherlands; New Zealand; Switzerland (SDC); United Kingdom (DFID); the World Bank; and the Asian Development Bank. The analysis covers 10 of the 42 SDG targets which are identified in this paper as both outcomes focused and supported by robust SDG indicators at the UN's tier one. The ten targets were selected to present a broad cross-section of the SDGs. Tables in the same format could be produced for all 42 SDG targets in the menu presented in Annex 3.

It is important to note that the analysis has significant limitations. Specifically, the tables do not include analysis of:

- data availability for the SDG indicators, although the choice of tier one SDG indicators means that the indicators are robust and data are available for a large number of countries (UN's tier one indicators must have data availability in at least $50 \%$ of UN countries)

- whether each SDG target is considered a policy priority by the provider, and whether there are related provider goals, outcomes, or objectives

- related indicators used by partner countries in their national development plans.

Despite these limitations, the tables shed light on strong existing links and relationships between provider standard indicator sets and the SDG targets and indicators. As expected, there tend to be stronger links between standard indicators and SDG indicators in the more traditional human development areas (SDGs 2, 3, 6). There are also strong links for SDG 7 on energy. Links are weaker for Goals 5, 8, and 10.

However, despite the robust links between the standard indicators of providers and SDG targets, the tables highlight variance between provider indicators particularly at Tier 2 of results frameworks. For example, under target 6.2 providers utilise seven different indicators to measure the reach of sanitation interventions at Tier 2.

\section{Legend:}

- Blue highlight indicates a direct match with the relevant SDG indicator (these are all related to Tier 1 of the results frameworks)

- Yellow highlight shows indicators which are assessed as closely related to the SDG indicator and in some cases represent measurement of a contribution towards the outcome articulated in the SDG indicator

- $\mathrm{N} / \mathrm{A}=$ provider does not have indicators at this tier

- A dash ( - ) indicates no related or exact indicator match 


\begin{tabular}{|c|c|c|}
\hline SDG Target & \multicolumn{2}{|c|}{$\begin{array}{l}\text { 2.1. By } 2030 \text {, end hunger and ensure access by all people, in particular the poor and people in } \\
\text { vulnerable situations, including infants, to safe, nutritious and sufficient food all year round. }\end{array}$} \\
\hline SDG Indicator(s) & \multicolumn{2}{|c|}{$\begin{array}{l}\text { 2.1.1 Prevalence of undernourishment } \\
\text { 2.1.2 Prevalence of moderate or severe food insecurity in the population, based on the Food } \\
\text { Insecurity Experience Scale (FIES) }\end{array}$} \\
\hline $\begin{array}{l}\text { Provider standard } \\
\text { indicator }\end{array}$ & Tier one & Tier two \\
\hline $\begin{array}{l}\text { European } \\
\text { Commission }\end{array}$ & Prevalence of undernourishment & $\begin{array}{l}\text { Number of women of reproductive age and } \\
\text { children under } 5 \text { benefiting from nutrition related } \\
\text { programmes with EU support. }\end{array}$ \\
\hline Finland & - & $\begin{array}{l}\text { The number of smallholder farmers and food } \\
\text { producers that are reached by food security and } \\
\text { productivity-enhancing measures. }\end{array}$ \\
\hline Netherlands & - & Number of people with improved food intake \\
\hline New Zealand & $\begin{array}{l}\text { Prevalence of moderate or severe food } \\
\text { insecurity in the population (\%) }\end{array}$ & \\
\hline Switzerland- SDC & - & $\begin{array}{l}\text { yy nutrition relevant policies, laws, strategies and } \\
\text { plans developed at national level } \\
\text { xyx annual yield increase for a specific crop ( } \mathrm{kg} / \mathrm{ha} \text { ) } \\
\text { and for specific livestock ( } \mathrm{kg} \text { or I /animal) by yy } \\
\text { small farmers supported (M/F) }\end{array}$ \\
\hline $\begin{array}{l}\text { United Kingdom- } \\
\text { DFID }\end{array}$ & - & $\begin{array}{l}\text { Number of children under } 5 \text {, women (of } \\
\text { childbearing age) and adolescent girls reached by } \\
\text { DFID through nutrition-related interventions. }\end{array}$ \\
\hline $\begin{array}{l}\text { The World Bank } \\
\text { Group }\end{array}$ & $\begin{array}{l}\text { Malnutrition, height for age (percent, } \\
\text { children under 5) }\end{array}$ & - \\
\hline AsDB & Underweight children under 5 years old (\%) & - \\
\hline
\end{tabular}

\section{Goal 3. Ensure healthy lives and promote well-being for all at all ages}

\section{SDG Target}

\section{SDG Indicator(s)}

Provider standard indicator

European

Commission

Finland

Netherlands

New Zealand

\begin{tabular}{|l|l|}
\hline Switzerland- SDC & N/A \\
\hline
\end{tabular}

United Kingdom-

DFID

3.2. By 2030, end preventable deaths of new-borns and children under 5 years of age, with all countries aiming to reduce neonatal mortality to at least as low as 12 per 1,000 live births and under-5 mortality to at least as low as 25 per 1,000 live births.

3.2.1 Under-five mortality rate

3.2.2 Neonatal mortality rate

Tier one

Under five mortality rate

N/A

N/A

Under 5 mortality rate (deaths per 1000 live births)

\section{Tier two}

Number of one year olds immunised with EU support

$-$

People that have received essential medicines and care at primary health facilities (No. M/F)

yy number of births attended by skilled health personnel

Number of lives saved by immunising children against killer diseases.

Number of children under 5 , women (of childbearing age) and adolescent girls reached by DFID through nutrition-related interventions.

People who have received essential health,

The World Bank

Under 5 mortality rate (per 100 live births) 


\begin{tabular}{|l|l|l|}
\hline Group & \multicolumn{1}{|c|}{ nutrition and population services } \\
\hline AsDB & $\begin{array}{l}\text { Under } 5 \text { mortality rate (number per } 1000 \\
\text { live births) }\end{array}$ & - \\
\hline
\end{tabular}

\section{Goal 3. Ensure healthy lives and promote well-being for all at all ages}

SDG Target

\section{SDG Indicator(s)}

\section{Provider standard} indicator

European

Commission

Finland

N/A

$N / A$

Netherlands

\begin{tabular}{|c|c|c|}
\hline & & \\
\hline New Zealand & $\begin{array}{l}\text { Women } 15-49 \text { years who are sexually active } \\
\text { who have their need for family planning } \\
\text { satisfied with modern methods (\%) }\end{array}$ & - \\
\hline Switzerland- SDC & $N / A$ & - \\
\hline United Kingdom & N/A & $\begin{array}{l}\text { Number of additional women using modern } \\
\text { methods of family planning through DFID } \\
\text { support. }\end{array}$ \\
\hline $\begin{array}{l}\text { The World Bank } \\
\text { Group }\end{array}$ & - & - \\
\hline AsDB & - & - \\
\hline
\end{tabular}

\section{Goal 5. Achieve gender equality and empower all women and girls}

\section{SDG Target}

SDG Indicator(s)

\section{Provider standard} indicator

European

Commission

Finland

5.5 Ensure women's full and effective participation and equal opportunities for leadership at all levels of decision-making in political, economic and public life.

5.5.1. Proportion of seats held by women in (a) national parliaments and (b) local governments 5.5.2 Proportion of women in managerial positions

\section{Tier one}

Proportion of seats held by women in national parliaments

$N / A$

N/A

Netherlands

New Zealand

Switzerland- SDC

United Kingdom

The World Bank

Group

AsDB

\section{Proportion of seats held by women in} national parliaments (\%)

$$
\text { N/A }
$$

N/A

Countries with equal opportunities for women in law (number)

\section{Tier two}

Number of women using any method of contraception with EU support

Number of women and girls using sexual and reproductive health services

The additional number of women (or their partners) of reproductive age using a modern contraceptive method 
Goal 6. Ensure availability and sustainable management of water and sanitation for all

\begin{tabular}{|c|c|c|}
\hline SDG Target & \multicolumn{2}{|c|}{ 6.1. By 2030, achieve universal and equitable access to safe and affordable drinking water for all. } \\
\hline SDG Indicator(s) & \multicolumn{2}{|c|}{ 6.1.1. Proportion of population using safely managed drinking water service } \\
\hline $\begin{array}{l}\text { Provider standard } \\
\text { indicator }\end{array}$ & Tier one & Tier two \\
\hline $\begin{array}{l}\text { European } \\
\text { Commission }\end{array}$ & $\begin{array}{l}\text { Proportion of the population using an } \\
\text { improved drinking water source }\end{array}$ & - \\
\hline Finland & N/A & $\begin{array}{l}\text { The number of people benefiting from safe and } \\
\text { sustainable water supply and sanitation systems. }\end{array}$ \\
\hline Netherlands & N/A & $\begin{array}{l}\text { Number of people with access to safe and } \\
\text { affordable drinking water }\end{array}$ \\
\hline New Zealand & $\begin{array}{l}\text { Population using a safely managed drinking } \\
\text { water sources (\%) }\end{array}$ & $\begin{array}{l}\text { People provided new or improved water supply } \\
\text { (No.,M/F) }\end{array}$ \\
\hline Switzerland- SDC & N/A & $\begin{array}{l}\text { yy water related policies, laws, strategies and } \\
\text { plans developed at national level } \\
\text { yy people (M/F) gained new access to safe and } \\
\text { affordable drinking water }\end{array}$ \\
\hline United Kingdom & N/A & $\begin{array}{l}\text { Number of people with sustainable access to } \\
\text { clean water and/or sanitation through DFID } \\
\text { support }\end{array}$ \\
\hline $\begin{array}{l}\text { The World Bank } \\
\text { Group }\end{array}$ & $\begin{array}{l}\text { Access to safe water within a household } \\
\text { (percent, bottom 40\%/ gap to average) }\end{array}$ & $\begin{array}{l}\text { People provided with access to an improved } \\
\text { water source (millions) }\end{array}$ \\
\hline AsDB & $\begin{array}{l}\text { Population using an improved drinking water } \\
\text { source (\%) (urban/ rural) }\end{array}$ & Households with new or improved water supply \\
\hline
\end{tabular}

\section{Goal 6. Ensure availability and sustainable management of water and sanitation for all}

\section{SDG Target}

SDG Indicator(s)

\section{Provider standard} indicator

European

Commission

Finland

N/A

Netherlands

New Zealand

Switzerland- SDC

N/A

Population using safely managed sanitation services (\%)

N/A

N/A

United Kingdom

The World Bank

Group

AsDB vulnerable situations. washing facility with soap and water

Proportion of the population using an improved sanitation facility

Access to improved sanitation (percent overall population)

Population using an improved sanitation
facility (\%) (urban/rural)
6.2. By 2030, achieve access to adequate and equitable sanitation and hygiene for all and end open defecation, paying special attention to the needs of women and girls and those in

6.2.1. Proportion of population using safely managed sanitation services, including a hand-

\begin{tabular}{l|l} 
Tier one & Tier two
\end{tabular}

\begin{tabular}{l|l}
\hline A & The number of people benefiting from safe and
\end{tabular} sustainable water supply and sanitation systems. Number of people with access to adequate sanitation

People with new or improved basic sanitation (No., M/F)

yy people (M/F) gained new access to adequate and equitable sanitation and hygiene

Number of people with sustainable access to clean water and/or sanitation through DFID support.

People provided with access to improved sanitation services (millions) (number) 
Goal 7. Ensure access to affordable, reliable, sustainable and modern energy for all

SDG Target

SDG Indicator(s)

\section{Provider standard} indicator

\section{European}

Commission

Finland

Netherlands

New Zealand

Switzerland- SDC

United Kingdom

The World Bank Group

Asian Development Bank

7.1. By 2030, ensure universal access to affordable, reliable and modern energy services.

7.1.1. Proportion of population with access to electricity

7.1.2. Proportion of population with primary reliance on clean fuels and technology

Tier one

Percentage of the population with access to energy services

N/A

N/A

Proportion of population with primary reliance on clean fuels and technology (\%)

N/A

N/A

Access to electricity (percent, bottom $40 \%$ /gap to average)

Electrification rate $\%$

\section{Tier two}

Number of people provided with access to sustainable energy services with EU support

Number of households with access to climateresistant energy services.

Number of people with access to renewable energy

People provided with new or improved electricity supply (No., M/F)

yy energy related policies, laws, strategies and plans developed at national level

People provided with new or improved electricity service

New households connected to electricity

\section{Goal 7. Ensure access to affordable, reliable, sustainable and modern energy for all}

\section{SDG Target}

SDG Indicator(s)

Provider standard indicator

\section{European}

Commission

Finland

Netherlands

Switzerland- SDC

United Kingdom

The World Bank

Group

Asian Development

Bank

7.2. By 2030, increase substantially the share of renewable energy in the global energy mix.

7.2.1. Renewable energy share in the total final energy consumption

Tier one

Renewable energy production as a proportion of total energy production N/A

$N / A$

Energy supplied through the main grids produced from renewable energy sources (\%)

$\mathrm{N} / \mathrm{A}$

N/A

\section{Tier two}

Renewable energy production supported by the $\mathrm{EU}$

Installed renewable energy capacity of new or upgraded infrastructure (Megawatts)

Renewable energy generated/produced per annum (Megawatts/hour)

Expanded conventional/renewable power generation (gigawatt hours, annual) Installed energy generation capacity - renewable 


\section{SDG Target}

SDG Indicator(s)

Provider standard indicator

\begin{tabular}{l|l}
\hline $\begin{array}{l}\text { European } \\
\text { Commission }\end{array}$ & - \\
\hline Finland & - \\
\hline Netherlands & - \\
\hline New Zealand & Employment-to-population ratio (\%) \\
\hline
\end{tabular}

N/A

\section{Tier one}

(o)

8.5. By 2030, achieve full and productive employment and decent work for all women and men, including for young people and persons with disabilities, and equal pay for work of equal value.

8.5.2. Unemployment rate, by sex, age and persons with disabilities

\section{Tier two}

Number of people who have benefitted from VET/ skills development and other active labour market programmes with EU support

Number of private sector jobs supported Direct jobs supported

People that complete vocational training (No. $\mathrm{M} / \mathrm{F}$ )

$\mathrm{xx}$ youth (15-24 yrs) and yy adults (>24 yrs) (M/F) gained access to improved vocational skills. Out of these, zx youth and zy adults (M/F) received vocational skills training combined with basic education on the one hand, and on the other hand wx youth and wy adults (M/F) gained access to gainful employment or selfemployment

Switzerland- SDC

United Kingdom

The World Bank

Group

Asian Development

Bank
People, microenterprises and SMEs reached with financial services (millions)

Microfinance loan accounts opened or end borrowers reached (number) ( $\mathrm{m} / \mathrm{f}$ )

\section{Goal 10. Reduce inequality within and among countries}

\begin{tabular}{|l|l|l|}
\hline SDG Target & $\begin{array}{l}\text { 10.1. By 2030, progressively achieve and sustain income growth of the bottom } 40 \text { per cent of the } \\
\text { population at a rate higher than the national average. }\end{array}$ \\
\hline SDG Indicator(s) & $\begin{array}{l}\text { 10.1.1. Growth rates of household expenditure or income per capita among the bottom } 40 \text { per } \\
\text { cent of the population and the total population }\end{array}$ & Tier two \\
\hline $\begin{array}{l}\text { Provider standard } \\
\text { indicator }\end{array}$ & Tier one & - \\
\hline $\begin{array}{l}\text { European } \\
\text { Commission }\end{array}$ & $\begin{array}{l}\text { Income share held by the lowest } 40 \% \text { of } \\
\text { income distribution (\% income period } \\
\text { averages) }\end{array}$ & - \\
\hline Finland & N/A & - \\
\hline Netherlands & N/A & - \\
\hline New Zealand & - & - \\
\hline Switzerland- SDC & N/A & - \\
\hline United Kingdom & N/A \\
\hline $\begin{array}{l}\text { The World Bank } \\
\text { Group }\end{array}$ & $\begin{array}{l}\text { Median of growth rates of average real per } \\
\text { capita income of the bottom 40\% (percent) }\end{array}$ & - \\
\hline $\begin{array}{l}\text { Asian Development } \\
\text { Bank }\end{array}$ & $\begin{array}{l}\text { Countries with high income inequality (\% of } \\
\text { countries with Gini coefficient exceeding 0.4) }\end{array}$ & - \\
\hline
\end{tabular}


For those providers which use Tier 1 indicators (four of the eight providers), there were a number of exact matches between SDG indicators and provider indicators at Tier 1 (shaded blue in the tables). This is encouraging in itself. However, how providers summarise and communicate the results from these SDG indicators at Tier 1 - whether by region, country, or as an aggregate of all the countries a provider supports is important to consider. In theory, the data can only be used for decision-making where it is summarised by country. In fact, many providers may be more likely to use SDG indicators at Tier 1 in their country-level frameworks, allowing insights and dialogue on progress or not towards the specific targets which partners prioritise and how providers can contribute to these.

At Tier 2 of results frameworks, a number of indicators were found to have a direct relationship with the corresponding SDG indicator. In particular, there were instances where provider indicators were counting the number of beneficiaries reached via a certain intervention (output), where the corresponding SDG indicator measures the proportion of an overall population that has access to this service. The indicators effectively make use of the same dataset, but present it at different levels along the results chain. For example:

For the SDG target 3.7:

3.7. By 2030, ensure universal access to sexual and reproductive health-care services, including for family planning, information and education, and the integration of reproductive health into national strategies and programmes.

The first indicator is as follows:

3.7.1. Proportion of women of reproductive age (aged 15-49 years) who have their need for family planning satisfied with modern methods

The following four providers have indicators which are directly related to 3.7.1:

\begin{tabular}{|l|l|}
\hline $\begin{array}{l}\text { Provider } \\
\text { European } \\
\text { Commission }\end{array}$ & Tier $\mathbf{2}$ standard indicators \\
\hline Finland & Number of women using any method of contraception with EU support \\
\hline Netherlands & $\begin{array}{l}\text { Number of women and girls using sexual and reproductive health services } \\
\text { contraceptive method }\end{array}$ \\
\hline United Kingdom & $\begin{array}{l}\text { Number of additional women using modern methods of family planning through DFID } \\
\text { support. }\end{array}$ \\
\hline
\end{tabular}

Similarly for target 7.1:

7.1. By 2030, ensure universal access to affordable, reliable and modern energy services.

And its related indicators:

7.1.1. Proportion of population with access to electricity

The following seven providers have indicators which are directly related to 7.1.1:

\begin{tabular}{|l|l|}
\hline $\begin{array}{l}\text { Provider } \\
\text { European } \\
\text { Commission }\end{array}$ & Tier $\mathbf{2}$ standard indicators \\
\hline Finland & Number of people provided with access to sustainable energy services with EU support \\
\hline
\end{tabular}




\begin{tabular}{|l|l|}
\hline Provider & Tier $\mathbf{2}$ standard indicators \\
\hline Netherlands & Number of people with access to renewable energy \\
\hline New Zealand & People provided with new or improved electricity supply (No., M/F) \\
\hline $\begin{array}{l}\text { Switzerland - SDC } \\
\begin{array}{l}\text { The World Bank } \\
\text { Group }\end{array}\end{array}$ & yy energy related policies, laws, strategies and plans developed at national level \\
\hline $\begin{array}{l}\text { Asian } \\
\text { Development } \\
\text { Bank }\end{array}$ & New households connected to electricity \\
\hline
\end{tabular}

Providers are using the standard indicators above to measure the outputs of interventions they fund. The data they are using likely come from national or sub-national administrative data and are a sub-set of the data that are used by partner countries to measure and report against SDG targets and indicators. For example, indicators 3.7.1 and 7.1.1 (the examples used above) are included in Kenya's national SDG indicator framework (Ministry of Devolution and Planning, Kenya, 2017). Moreover, partners may be required by providers to report data against their standard indicator at Tier 2 (in a slightly different form for each provider).

\section{Provider standard indicator sources:}

European commission: EU International Cooperation and Development Results Framework: https://ec.europa.eu/europeaid/staff-working-document-launching-eu-international-cooperation-and-developmentresults-framework en

Finland: MFA (2017), "Aggregate indicators for 2016 Development Policy", unpublished.

Netherlands: Indicator list and methodological notes:

https://www.rijksoverheid.nl/binaries/rijksoverheid/documenten/kamerstukken/2017/03/16/bijlage-kamerbrief-inzakeaanbieding-methodologische-notities/15+methodological+notes+-+final.pdf

New Zealand: Indicator list by sector: https://www.mfat.govt.nz/assets/Aid-Prog-docs/Tools-and-guides/SRF-2-pagerindicators-V7-2016-2017.pdf

Switzerland: SDC (2016) SDC Guidelines on the use of aggregated reference indicators for reporting and monitoring the dispatch 2017-2020, unpublished.

United Kingdom: Indicators and methodological notes can be accessed here:

https://www.gov.uk/government/publications/dfid-single-departmental-plan-methodology-notes

Full indicator list in United Kingdom results case study

World Bank Group. Corporate scorecard: http://scorecard.worldbankgroup.org/

Asian Development Bank: AsDB Results Framework: https://www.adb.org/sites/default/files/institutionaldocument/154037/adb-results-framework-interim-update.pdf 


\section{References}

Ministry of Devolution and Planning, Kenya (2017), "Implemementation of the Agenda 2030 for Sustainable Development in Kenya", June, 2017, www.sustainabledevelopment.un.org/content/documents/15689Kenya.pdf.

OECD (2018), "Development co-operation results for the 2030 Agenda: A guide for applying the Sustainable Development Goals, targets and indicators in results frameworks", OECD, Paris.

OECD (2017a), "Key Messages from Results Community Workshop, 9-10 October 2017", OECD, Paris, http://www.oecd.org/dac/results-development/docs/Results-oct-2017-Key-Messages.pdf

OECD (2017b), Strengthening the results chain: Synthesis of results-based management by providers, OECD, Paris, http://dx.doi.org/10.1787/544032a1-en.

OECD (2017c), "Making better use of results data in development co-operation", in Development Co-operation Report 2017: Data for Development, OECD Publishing, Paris, http://dx.doi.org/10.1787/dcr-2017-en.

OECD (2017d), "Capturing the 2030 Agenda in development co-operation results: SDGs, targets, indicators, and Leave no one behind", OECD, Paris, www.oecd.org/dac/results-development/docs/2030-Agenda-in-results.pdf.

OECD (2017e), "Development co-operation results under the 2030 Agenda: Challenges and opportunities in results monitoring", OECD, Paris, http://www.oecd.org/dac/results-development/docs/Results\%20and\%20development\%20cooperation\%20for\%202030.pdf

OECD/UNDP (2016) Making Development Co-operation More Effective: 2016 Progress Report, OECD Publishing, Paris, http://dx.doi.org/10.1787/9789264266261-en.

UN (2017), "Repositioning the United Nations development system to deliver on the 2030 Agenda: ensuring a better future for all", Report of the Secretary-General, United Nations, 11 July 2017, undocs.org/A/72/124.

UNStats (2017), "Tier Classification for Global SDG Indicators", United Nations Statistics, 20 April 2017, unstats.un.org/sdgs/files/Tier\%20Classification\%20of\%20SDG\%20Indicators 20\%20April\%202017 web.pdf.

\section{Notes}

\footnotetext{
${ }^{1}$ The GPEDC is updating its $1^{\text {st }}$ monitoring indicator (on the use of country results frameworks) to achieve precisely this purpose.
}

${ }^{2}$ The paper uses Tier 1, Tier 2 and Tier 3, with a capital T, for the three tiers of providers' results frameworks (see Annex 1).

${ }^{3}$ The UN's Statistical Commission has agreed on three tiers of SDG indicators, where tier one refers to indicators with the strongest methodology and the best available data. The concept of "robust SDG indicators" is used in this paper for tier one indicators. The number of robust / tier one SDG indicators should gradually increase as better country data become available.

${ }^{4}$ The paper discussed at the October 2017 workshop of the DAC/DCD Results Community included preliminary analyses of the approaches taken by developing countries to incorporate the 2030 Agenda in their national planning and development co-operation management. See OECD (2017d)

${ }^{5}$ See http://www.oecd.org/dac/results-development/results-community.htm

${ }^{6}$ See for example the World Bank management's response to the independent evaluation of Results and Performance of the World Bank Group 2016, http://ieg.worldbankgroup.org/sites/default/files/Data/Evaluation/files/rap2016.pdf (xvi)

${ }^{7}$ Development Assistance Committee, DAC; Global Partnership for Effective Development Co-operation, GPEDC; UN High Level Political Forum, UN-HLPF; UN Development Cooperation Forum, UN-DCF.

${ }^{8}$ The tier classification of SDG indicators adopted by the UN Statistical Commission is: "Tier 1: Indicator is conceptually clear, has an internationally established methodology and standards are available, and data are regularly produced by countries for at least 50 per 
cent of countries and of the population in every region where the indicator is relevant. Tier 2: Indicator is conceptually clear, has an internationally established methodology and standards are available, but data are not regularly produced by countries. Tier 3: No internationally established methodology or standards are yet available for the indicator, but methodology/standards are being (or will be) developed or tested." See UNStats (2017).

${ }^{9}$ Each of SDGs 1 through 16 includes two sets of numbered targets. In paragraph 40 of the UN General Assembly's Outcome Document on the 2030 Agenda for Sustainable Development, the targets that are numbered with a, b, c etc. are referred to as MOI targets. All 19 targets under SDG17 are also referred to as MOI targets (although they are numbered with numbers and not letters).

${ }^{10}$ This continued MDG focus was relayed by the UN Secretary-General in the recent report "Repositioning the UN development system to deliver on the 2030 Agenda - Ensuring a Better Future for All" (UN, 2017). It finds that "the UN development system is still to complete its transition from the MDGs to the 2030 Agenda for Sustainable Development. For example, over 50 per cent of the system's budget is still concentrated in the first six SDGs. This reflects a continuing focus on MDG-like interventions and highlights the need to embrace conceptually and substantively the full sustainable development agenda captured in the 17 SDGs." (UN, 2017: 8).

${ }^{11}$ See the Paris Agreement, http://unfccc.int/meetings/paris nov 2015/items/9445.php

12 "The list includes $\mathbf{2 3 2}$ indicators on which general agreement has been reached. Please note that the total number of indicators listed in the revised global list of SDG indicators is 244 . However, since nine indicators repeat fewer than two or three different targets, the actual total number of individual indicators in the list is $232 . "$ See https://unstats.un.org/sdgs/indicators/indicators-list/

${ }^{13}$ Relative to the list included in a paper of January 2017, see OECD (2017e), two targets (10.4 and 12.4) have been added to the list of "outcome-oriented" targets because of the existence of robust indicators, as per the latest decisions of the UN Statistical Commission.

14 "As of 20 April 2017, the updated tier classification contains 82 Tier I indicators, 61 Tier II indicators and 84 Tier III indicators. In addition, there are 5 indicators that have multiple tiers (different components of the indicators are classified into different tiers)." (UNSTATS, 2017; 3)

${ }^{15}$ SDG17 on partnerships deals with means of implementation only and not with outcome results.

${ }^{16}$ See the definition of country-led results frameworks in Annex 1.

${ }^{17}$ A further $10 \mathrm{MOI}$ targets were found to be directly relevant to development co-operation, but did not yet have corresponding robust indicators, bringing coverage up to $17 / 17$ goals.

${ }^{18}$ Based on World Bank Group Corporate Scorecard indicators available at the time of analysis. The corporate scorecard indicators were reported in October 2016. See http://scorecard.worldbankgroup.org/ 